\title{
Comparisons of Videolaryngoscopes for Intubation Undergoing General Anesthesia: Systematic Review and Network Meta-Analysis of Randomized Controlled Trials
}

\author{
Juncheol Lee ${ }^{1, \dagger}{ }^{+}$Youngsuk Cho ${ }^{2,3,+} \oplus$, Wonhee Kim ${ }^{4, *}{ }^{\oplus}$, Kyu-Sun Choi ${ }^{5}$, Bo-Hyoung Jang ${ }^{6}$, Hyungoo Shin ${ }^{1}(\mathbb{D}$, \\ Chiwon Ahn ${ }^{7}{ }^{\circ}$, Jae Guk Kim $\left.{ }^{4}{ }^{(}\right)$, Min Kyun Na ${ }^{5}$, , Tae Ho Lim ${ }^{1}$ and Dong Won Kim ${ }^{8}$
}

check for updates

Citation: Lee, J.; Cho, Y.; Kim, W.; Choi, K.-S.; Jang, B.-H.; Shin, H.; Ahn, C.; Kim, J.G.; Na, M.K.; Lim, T.H.; et al. Comparisons of

Videolaryngoscopes for Intubation Undergoing General Anesthesia: Systematic Review and Network Meta-Analysis of Randomized Controlled Trials. J. Pers. Med. 2022, 12,363. https://doi.org/10.3390/ jpm12030363

Academic Editors: Laura Ruggeri and Francesca Fumagalli

Received: 11 January 2022 Accepted: 24 February 2022 Published: 26 February 2022

Publisher's Note: MDPI stays neutral with regard to jurisdictional claims in published maps and institutional affiliations.

Copyright: (c) 2022 by the authors. Licensee MDPI, Basel, Switzerland. This article is an open access article distributed under the terms and conditions of the Creative Commons Attribution (CC BY) license (https:// creativecommons.org/licenses/by/ $4.0 /)$.
1 Department of Emergency Medicine, Hanyang University College of Medicine, Seoul 04763, Korea; doldoly@hanyang.ac.kr (J.L.); seodtst@gmail.com (H.S.); erthim@gmail.com (T.H.L.)

2 Department of Emergency Medicine, Hallym University, Kangdong Sacred Heart Hospital, Seoul 05355, Korea; faith2love@gmail.com

3 Department of Biomedical Engineering, Hanyang University College of Medicine, Seoul 04763, Korea

4 Department of Emergency Medicine, Hallym University, Chuncheon 24253, Korea; gallion00@gmail.com

5 Department of Neurosurgery, Hanyang University College of Medicine, Seoul 04763, Korea; vertex-09@hanmail.net (K.-S.C.); mavmav@hanmail.net (M.K.N.)

6 Department of Preventive Medicine, College of Korean Medicine, Kyung Hee University, Seoul 02447, Korea; bhjang@khu.ac.kr

7 Department of Emergency Medicine, College of Medicine, Chung-Ang University, Seoul 06974, Korea; cahn@cau.ac.kr

8 Department of Anesthesiology and Pain Medicine, Hanyang University College of Medicine, Seoul 04763, Korea; dongwkim@hanyang.ac.kr

* Correspondence: wonsee02@gmail.com; Tel.: +82-2-829-5561; Fax: +82-2-842-4217

+ These authors contributed equally to this work.

\begin{abstract}
Background: The efficacy and safety of videolaryngoscopes (VLs) for tracheal intubation is still conflicting and changeable according to airway circumstances. This study aimed to compare the efficacy and safety of several VLs in patients undergoing general anesthesia. Methods: Medline, EMBASE, and the Cochrane Library were searched until 13 January 2020. The following VLs were evaluated compared to the Macintosh laryngoscope (MCL) by network meta-analysis for randomized controlled trials (RCTs): Airtraq, Airwayscope, C-MAC, C-MAC D-blade (CMD), GlideScope, King Vision, and McGrath. Outcome measures were the success and time (speed) of intubation, glottic view, and sore throat (safety). Results: A total of 9315 patients in 96 RCTs were included. The highestranked VLs for first-pass intubation success were CMD (90.6\% in all airway; $92.7 \%$ in difficult airway) and King Vision (92\% in normal airway). In the rank analysis for secondary outcomes, the following VLs showed the highest efficacy or safety: Airtraq (safety), Airwayscope (speed and view), C-MAC (speed), CMD (safety), and McGrath (view). These VLs, except McGrath, were more effective or safer than MCL in moderate evidence level, whereas there was low certainty of evidence in the intercomparisons of VLs. Conclusions: CMD and King Vision could be relatively successful than MCL and other VLs for tracheal intubation under general anesthesia. The comparisons of intubation success between VLs and MCL showed moderate certainty of evidence level, whereas the intercomparisons of VLs showed low certainty evidence.
\end{abstract}

Keywords: laryngoscopes; anesthesia; intubation; systematic review; meta-analysis

\section{Introduction}

The tracheal intubation during general anesthesia can be often unsuccessful. Although the intubation is successful, it can cause several complications. These included respiratory (sore throat, airway trauma), hemodynamic (bradycardia, tachycardia, hypotension) or mechanical complications (mucosal bleeding, dental injury) [1,2]. Difficult intubation 
occurs in $1.8-5.8 \%$ of patients, and failed intubation occurs less frequently but still in $0.13-0.30 \%$ of cases [2-4].

The Mallampati score, mouth opening, and thyromental distance, as well as body mass index, have all been established as predictors of difficult intubation. When patients are obese, have limited neck movement, have a narrow jaw opening, an enlarged tongue, or have poor tissue mobility, airway difficulties rise. [5-7]. Several types of videolaryngoscopes (VLs) have been developed to overcome these difficult airways and make intubation successful by providing better glottic view. VLs are categorized into channeled (without stylet) versus non-channeled (with stylet). Channeled VLs include Airtraq, Airwayscope and King Vision, whereas non-channeled VLs include GlideScope, C-MAC, C-MAC Dblade (CMD), and McGrath. Although it appears that the mechanism of VL is helpful in increasing success rates, several randomized controlled trials (RCTs) have suggested that VLs are surprisingly not more effective than MCL [8-14]. However, the results of all existing meta-analyses are still conflicting and are limited to the comparison of specific VL and MCL [15-19].

To identify relative superiority among several VLs for patient outcomes, the use of network meta-analysis can be appropriate. It can analyze and rank the efficacy of specific VL comparing with other VL as well as MCL. We aimed to identify the most effective and safest VL for tracheal intubation undergoing surgery considering airway circumstances by performing network meta-analysis.

\section{Methods}

\subsection{Literature Search}

This systematic review and network meta-analysis of RCTs is based on the Preferred Reporting Items for Systematic Reviews and Meta-analysis (PRISMA). The study protocol was registered with PROSPERO (CRD42019126284).

Two investigators (B.-H.J. and K.-S.C.) constructed the search strategy and other two investigators (Y.C. and K-S.C.) provided formal review. We conducted a search of Medline, EMBASE, and the Cochrane Library from their inception to 30 January 2020. To ensure high sensitivity in our search, we designed search strategies that included pertinent $\mathrm{MeSH}$ keywords, common keywords, and their comprehensive combination. The product name of VLs were also included in our search criteria. There were no restrictions on languages, and no filters were applied in this search. Details of the search strategy are described in Document S1.

\subsection{Data Selection}

We contrived a question based on population, intervention, comparison, and outcome (PICO). The PICO question was as follows: P-adult patients who required tracheal intubation during general anesthesia for elective surgery; I-VLs having independent video display for indirect vision; C-MCL direct laryngoscope with any VL with video display except intervention; $\mathrm{O}$ - the success rate for the first attempt intubation. Patients who underwent emergency surgery while under general anesthesia were not included in the study. The VLs included in this review were Airtraq (Prodol, Vizcaya, Spain), Airwayscope (Nihon Kohden, Tokyo, Japan), C-MAC (Karl Storz, Tuttlingen, Germany), CMD (Karl Storz, Tuttlingen, Germany), GlideScope(Verathon, WA, USA), King Vision(Ambu, Copenhagen, Denmark), and McGrath (Medtronic, Dublin, Ireland) (Figure 1). The following VLs were excluded due to insufficient articles to perform network meta-analysis: Trueview, A.P. Advance, UE scope, UE video intubation stylet. The use of King Vision as a non-channeled VL was excluded. The Optic stylet relying on direct vision through an embedded fiberoptic bundle was excluded. 


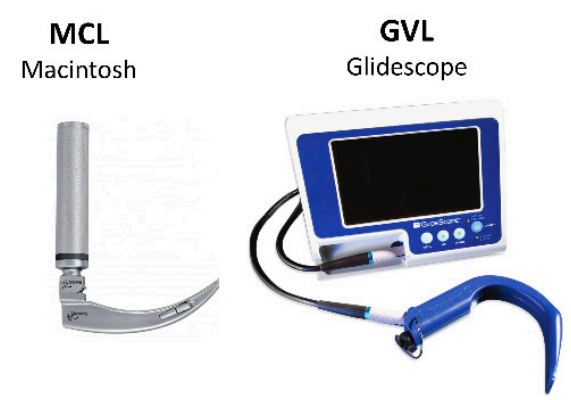

AWS

Airwayscope

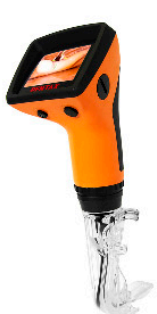

CM

C-MAC

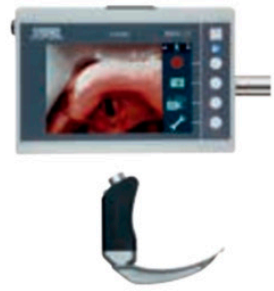

ATQ

Airtraq

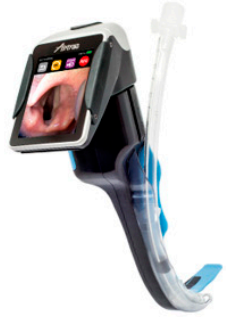

CMD

C-MAC D-blade

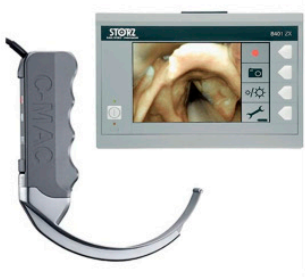

MG

McGrath

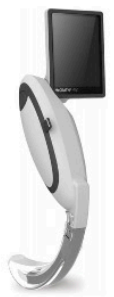

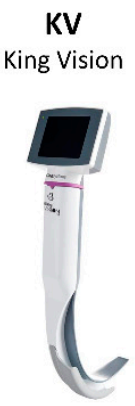

Figure 1. Type of videolaryngoscope. MCL, Macintosh direct laryngoscope; ATQ, Airtraq video laryngoscope; AWS, Pentax Airwayscope; CM, C-MAC video laryngoscope; CMD, C-MAC D-Blade video laryngoscope; GVL, GlideScope; KV, King Vision video laryngoscope; MG, McGrath video laryngoscope.

\subsection{Data Identification and Extraction}

The study data were collected and extracted using a standardized form. Two investigators (W.K. and J.L.) independently screened articles by title, abstract, and full texts according to the prespecified inclusion criteria. A full-text review was subsequently performed for potentially relevant articles. Any discrepancies were resolved by consensus after consulting a third investigator (Y.C.). The inclusion criteria were as follows: (1) adult patients who underwent tracheal intubation by experienced anesthetists during general anesthesia, and (2) RCT studies published in English for VL or MCL. The exclusion criteria were (1) nonrelevant intervention, (2) studies that failed to acquire outcomes of interest, (3) non-adult studies, and (4) non-RCTs such as review letters, before and after studies, observational studies, case-control studies, case reports, pre-prints, and conference abstracts.

\subsection{Outcome Measures}

The primary outcome of efficacy was the success rate for first-attempt intubation. The success of intubation was defined by capnography confirmation. Other success outcomes measured by chest rise or visual confirmation using VL were excluded. The secondary outcomes were intubation time, glottic view on the first attempt of intubation, and the incidence of sore throat within $24 \mathrm{~h}$. The intubation time was defined as the time from picking up the laryngoscope to confirmation by capnography. The glottic view was assessed using the Cormack-Lehane grade (CLG, I-IV) or modified CLG. The good-glottic view was also defined as CLG I-II or modified CLG I and IIa [20]. Better efficacy or safety means a higher success rate, shorter intubation time, better glottic view, and lower incidence of sore throat. These four outcomes were evaluated by three categories of airway status (all vs. normal vs. difficult airway). All airways were defined as the normal airway mixed with a difficult airway. Normal airway was additionally defined as airway circumstance that did not predict a difficult airway. Difficult airways were predicted using the following definitions: morbidly obese participants (body mass index $>35 \mathrm{~kg} / \mathrm{m}^{2}$ ); patients with immobilized cervical spines; Mallampati classification 4; retrognathia; more than one of 
the following: Mallampati classification 3, inter-incision distance of $35 \mathrm{~mm}$ or less, and a thyromental distance of $65 \mathrm{~mm}$ or less [21,22].

\subsection{Quality Assessment}

Quality assessment was also independently performed by the reviewers using the risk of bias tool developed by the Cochrane group [23]. Evaluated biases included: (1) random sequence generation; (2) allocation concealment; (3) blinding of participants and personnel; (4) blinding of outcome assessments; (5) incomplete outcome data; (6) selective reporting; and (7) other bias. The methodological quality of the identified studies was assessed independently by W.K. and J.L. Investigators selected the terms "low risk of bias," "high risk of bias," or "unclear" to define each study. Any disagreements between the investigators were resolved by a third investigator.

\subsection{Reporting Guidelines and Certainty of Evidence}

The modified Grades of Recommendation, Assessment, Development and Evaluation (GRADE) tool for network meta-analysis was used to evaluate the quality of evidence [24]. The quality of the results were classified as follows: (1) high quality-further research is very unlikely to change the confidence in the estimated effect; (2) moderate quality-further research is likely to have an important impact on the confidence in the estimated effect and may change the estimate; (3) low quality-further research is very likely to have an important impact on the confidence in the estimated effect and is likely to change the estimate; and (4) very low quality, where any estimated effect is highly uncertain.

\subsection{Statistical Analysis}

Odds ratio (OR) with 95\% confidence interval (CI) was used to calculate the difference for dichotomous outcomes, while the standardized mean difference (SMD) with 95\% CI was used for continuous variables. If the studies only reported the median and measure of dispersion, the data were converted to mean and standard deviation assuming a normal distribution, by using two simple formulae.

We performed a frequentist network meta-analysis of aggregate data to obtain network estimates for the aforementioned outcomes of interest. The model framework used random effects to allow for apparent heterogeneity among studies in treatment comparison effects [25]. We conducted a pairwise meta-analysis to generate direct estimates for outcomes using a random-effects model.

Transitivity assumption, the distribution of patient, and study characteristics that modify treatment effects (effect modifiers) across treatment comparisons were explored to assess whether these characteristics were sufficiently similar between comparisons. Additionally, we evaluated the incoherence assumption (the statistical disagreement between direct and indirect evidence in a closed loop), locally using a loop-specific approach, and globally using a design by treatment interaction model.

The surface under the cumulative ranking curve (SUCRA) values and rankograms were used to present the hierarchy of interventions for each outcome [26]. SUCRA values show the percentage of effectiveness of each intervention compared to the hypothetically best intervention, which is always the best without uncertainty. The certainty of evidence was assessed using GRADEpro in the Cochrane group. Publication bias was evaluated using a comparison-adjusted funnel plot for network meta-analysis.

The results were considered statistically significant at a two-sided $p$-value of less than 0.05. All statistical analyses were performed using STATA 14.0 software (StataCorp, College Station, TX, USA).

\section{Results}

\subsection{Study and Patient Characteristics}

We included a total of 15,238 studies according to a prespecified search strategy. Thereafter, 5233 duplicates were removed, and a total of 10,005 studies were left. We 
excluded 9716 irrelevant studies based on the titles or abstracts, and 289 studies remained. After full-text review, a total of 193 studies were excluded for the following reasons: review articles $(n=25)$, animal studies $(n=12)$, studies with non-relevant interventions $(n=24)$, studies with non-relevant populations $(n=62)$, studies with non-relevant outcomes $(n=39)$, letters $(n=4)$, proceedings $(n=4)$, study protocols $(n=11)$, and non-English $(n=4)$. For the final meta-analysis, a total of 9315 patients were selected from 96 RCTs (Figure 2).

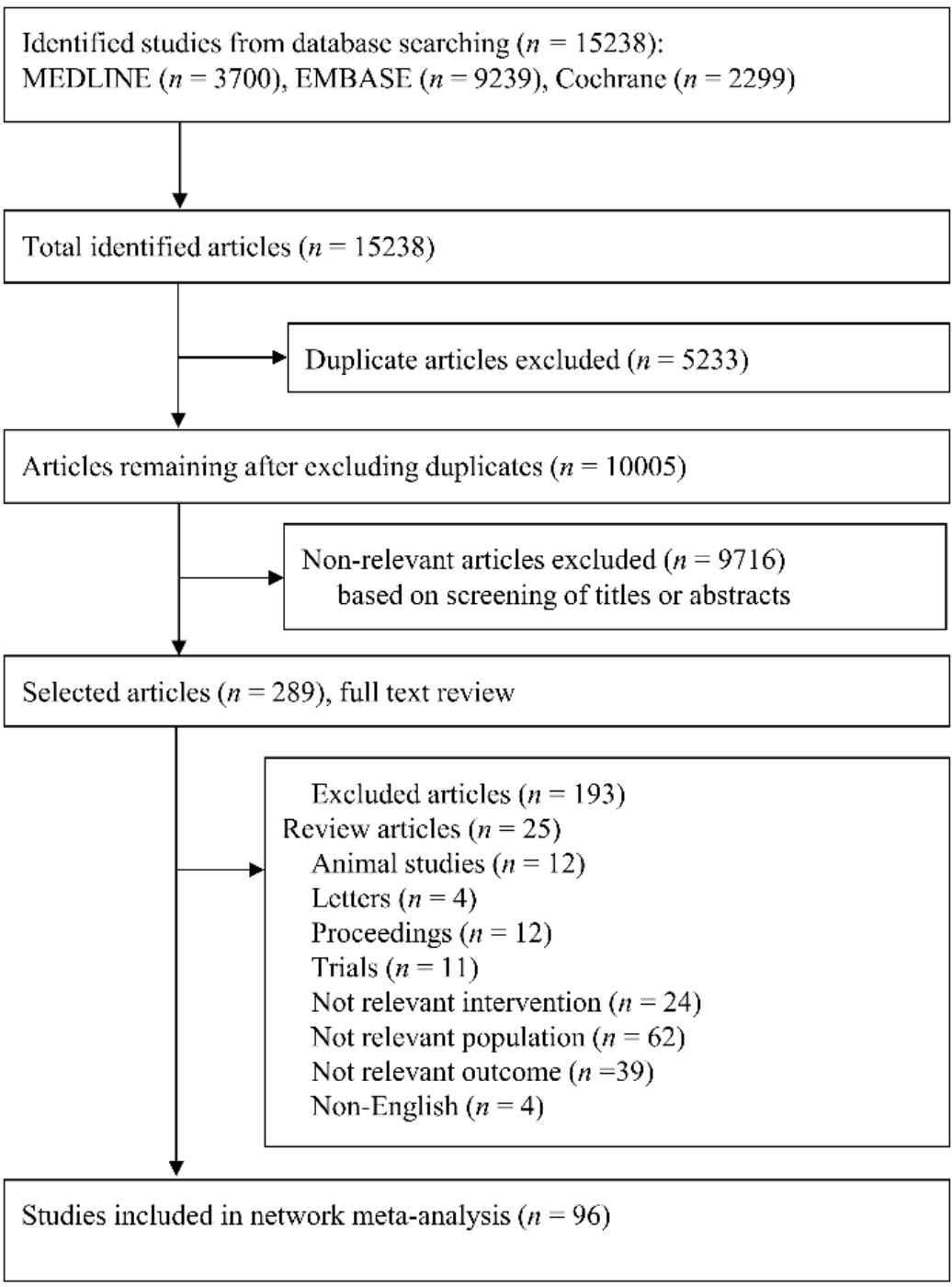

Figure 2. Preferred Reporting Items for Systematic Reviews and Meta-Analyses (PRISMA) flowchart of search strategy and study selection.

The characteristics of the included studies are shown in Table 1 [8-14,27-115]. The publication years for the included publications ranged from 2003-2018, and the number of patients ranged from 24 to 600. Seven types of VLs were included in this study, and the number of studies including each VLwere as follows: Airtraq $(n=27)$, Airwayscope $(n=16)$, C-MAC $(n=15)$, CMD $(n=8)$, GlideScope $(n=33)$, King Vision $(n=12)$, McGrath $(n=20)$. These VLs were compared with MCL in 77 studies. Intercomparisons of VLs were conducted in 19 studies. The number of VLS included in each study was as follows: two VLs $(n=85)$, three VLs $(n=7)$, four VLs $(n=3)$, and five VLs $(n=1)$. The top three comparisons for the most frequent VLs were as follows: GlideScope vs. MCL $(n=25)$; Airtraq vs. MCL $(n=19)$; Airwayscope vs. MCL $(n=13)$. The airway circumstances of the study population were classified into the following three categories: all airway $(n=23)$, normal airway $(n=33)$, and difficult airway $(n=40)$. 
Table 1. Characteristics of the included randomized controlled study

\begin{tabular}{|c|c|c|c|c|c|c|c|c|c|}
\hline Study, Year & Country & $\begin{array}{l}\text { Patients } \\
\text { Number }\end{array}$ & Airway Status & Devices & $\begin{array}{l}\text { Tracheal Tube } \\
\text { (Size; mm or Fr) }\end{array}$ & Success Rate (n) & $\begin{array}{l}\text { Intubation } \\
\text { Time (s) }\end{array}$ & $\begin{array}{l}\text { Good Glottic } \\
\text { View }(n)\end{array}$ & Sore Throat $(n)$ \\
\hline \multirow{2}{*}{ Abdallah, 2011} & \multirow{2}{*}{ USA } & \multirow{2}{*}{99} & \multirow{2}{*}{ Difficult } & MCL & ETT & $45 / 49$ & \multirow{2}{*}{$\mathrm{N} / \mathrm{A}$} & $38 / 49$ & $16 / 50$ \\
\hline & & & & AWS & $(7 / 7.5 \mathrm{~mm})$ & $43 / 50$ & & $43 / 50$ & $16 / 49$ \\
\hline \multirow{3}{*}{ Abdulmohsen, 2016} & \multirow{3}{*}{ Saudi Arabia } & \multirow{3}{*}{86} & \multirow{3}{*}{ Normal } & ATQ & ETT & $9 / 21$ & $56.4 \pm 6.02$ & $19 / 21 /$ & $6 / 21$ \\
\hline & & & & GVL & $(7 / 8 \mathrm{~mm})$ & $15 / 21$ & $41 \pm 6.41$ & $19 / 21$ & $16 / 21$ \\
\hline & & & & KV & & $15 / 22$ & $47.5 \pm 8.94$ & $22 / 22$ & $11 / 22$ \\
\hline \multirow{2}{*}{ Ahmed, 2017} & \multirow{2}{*}{ India } & \multirow{2}{*}{60} & \multirow{2}{*}{ Normal } & ATQ & \multirow{2}{*}{ ETT } & $27 / 30$ & \multirow{2}{*}{$\mathrm{N} / \mathrm{A}$} & $28 / 30$ & \multirow{2}{*}{$\mathrm{N} / \mathrm{A}$} \\
\hline & & & & $\hat{\mathrm{CM}}$ & & $28 / 30$ & & $28 / 30$ & \\
\hline \multirow{2}{*}{ Akbar, 2015} & \multirow{2}{*}{ Malaysia } & \multirow{2}{*}{90} & \multirow{2}{*}{ Difficult } & MCL & ETT & $39 / 45$ & $38.8 \pm 8.9$ & $42 / 45$ & \multirow{2}{*}{$\mathrm{N} / \mathrm{A}$} \\
\hline & & & & $\mathrm{CM}$ & $(7 / 7.5 / 8 \mathrm{~mm})$ & $44 / 45$ & $32.7 \pm 6.8$ & $43 / 45$ & \\
\hline \multirow{2}{*}{ Akbas, 2019} & \multirow{2}{*}{ Turkey } & \multirow{2}{*}{80} & \multirow{2}{*}{ Difficult } & CMD & ETT & $37 / 40$ & $38.65 \pm 17.57$ & \multirow{2}{*}{$\mathrm{N} / \mathrm{A}$} & \multirow{2}{*}{$\mathrm{N} / \mathrm{A}$} \\
\hline & & & & MG & $(7 / 7.5 \mathrm{~mm})$ & $37 / 40$ & $55.2 \pm 6.32$ & & \\
\hline \multirow{2}{*}{ Ali, 2012} & \multirow{2}{*}{ India } & \multirow{2}{*}{50} & $\Delta 11$ & MCL & FTT & $16 / 25$ & $36 \pm 16$ & $\mathrm{~N} / \mathrm{A}$ & $\mathrm{N} / \mathrm{A}$ \\
\hline & & & All & ATQ & E11 & $22 / 25$ & $48 \pm 18$ & $\mathrm{~N} / \mathrm{A}$ & $\mathrm{N} / \mathrm{A}$ \\
\hline$\Delta \mathrm{li} 2015$ & India & 50 & $\Delta 11$ & ATQ & FTT & $21 / 25$ & $38 \pm 18$ & $N / A$ & $N / A$ \\
\hline Ali 2017 & Indis & 60 & Difficultt & MCL & ETT & $27 / 30$ & & $24 / 30$ & \\
\hline & India & 60 & Difficult & KV & $(7 / 8 \mathrm{~mm})$ & $29 / 30$ & $\mathrm{~N} / \mathrm{A}$ & $28 / 30$ & $\mathrm{~N} / \mathrm{A}$ \\
\hline Amini 2015 & Iran & 70 & Normal & MCL & FTT & $N / A$ & $9.3 \pm 1.4$ & $N / A$ & $15 / 35$ \\
\hline Amini, 2015 & Iran & 70 & Normal & GVL & ETT & $\mathrm{N} / \mathrm{A}$ & $10.6 \pm 1.7$ & $\mathrm{~N} / \mathrm{A}$ & $13 / 35$ \\
\hline & & & & MCL & & $34 / 39$ & & & $4 / 36$ \\
\hline Ander, 2017 & Sweden & 78 & Difficult & $\mathrm{CM}$ & $(6 / 7 / 8 \mathrm{~mm})$ & $39 / 39$ & $\mathrm{~N} / \mathrm{A}$ & $\mathrm{N} / \mathrm{A}$ & $8 / 39$ \\
\hline & & & & MCL & ГTТ & $14 / 18$ & & $11 / 18$ & $4 / 18$ \\
\hline Aoi, 2010 & Japan & 36 & Difficult & AWS & ETT & $14 / 18$ & $\mathrm{~N} / \mathrm{A}$ & $18 / 18$ & $8 / 18$ \\
\hline & & & & MCL & ETT & $33 / 40$ & $41.3 \pm 15.2$ & $36 / 40$ & \\
\hline Aqil, 2016 & Saudi Arabia & 80 & Normal & GVL & $(7 / 8 \mathrm{~mm})$ & $34 / 40$ & $32.9 \pm 8.6$ & $39 / 40$ & $\mathrm{~N} / \mathrm{A}$ \\
\hline Agil 2017 & Saudi A rahia & 140 & Normal & MCL & ETT & $55 / 70$ & $N / \Delta$ & $56 / 70$ & $15 / 70$ \\
\hline Aq11, 2017 & Saudı Arabıa & 140 & Normal & GVL & $(7 / 8 \mathrm{~mm})$ & $64 / 70$ & $\mathrm{~N} / \mathrm{A}$ & $67 / 70$ & $7 / 70$ \\
\hline
\end{tabular}


Table 1. Cont.

\begin{tabular}{|c|c|c|c|c|c|c|c|c|c|}
\hline Study, Year & Country & $\begin{array}{l}\text { Patients } \\
\text { Number }\end{array}$ & Airway Status & Devices & $\begin{array}{l}\text { Tracheal Tube } \\
\text { (Size; } \mathrm{mm} \text { or Fr) }\end{array}$ & Success Rate (n) & $\begin{array}{l}\text { Intubation } \\
\text { Time (s) }\end{array}$ & $\begin{array}{l}\text { Good Glottic } \\
\text { View }(n)\end{array}$ & Sore Throat $(n)$ \\
\hline Arici, 2014 & Turkey & 80 & All & $\begin{array}{c}\text { MCL } \\
\text { MG }\end{array}$ & ETT & $\begin{array}{l}40 / 40 \\
40 / 40\end{array}$ & $\begin{array}{c}32.2 \pm 6.58 \\
47.25 \pm 14.92\end{array}$ & $\begin{array}{l}40 / 40 \\
38 / 40\end{array}$ & $\mathrm{~N} / \mathrm{A}$ \\
\hline Bakshi, 2019 & India & 74 & Normal & $\begin{array}{c}\text { MCL } \\
\text { MG }\end{array}$ & $\begin{array}{c}\text { ETT }^{*} \\
(35 / 37 / 39 \mathrm{Fr})\end{array}$ & $35 / 3736 / 37$ & $\begin{array}{l}56.6 \pm 14 \\
64.4 \pm 24\end{array}$ & $\begin{array}{l}36 / 37 \\
37 / 37\end{array}$ & $\mathrm{~N} / \mathrm{A}$ \\
\hline Belze, 2017 & France & 72 & Difficult & $\begin{array}{l}\text { ATQ } \\
\text { GVL }\end{array}$ & $\begin{array}{c}\text { ETT }^{*} \\
(35 / 37 / 39 / 41 \\
\text { Fr })\end{array}$ & $\begin{array}{l}28 / 36 \\
29 / 36\end{array}$ & $\mathrm{~N} / \mathrm{A}$ & $\begin{array}{l}36 / 36 \\
33 / 36\end{array}$ & $\begin{array}{l}34 / 36 \\
33 / 36\end{array}$ \\
\hline Bhandari, 2013 & India & 80 & Normal & $\begin{array}{l}\text { MCL } \\
\text { ATQ }\end{array}$ & ETT & $\begin{array}{l}38 / 40 \\
40 / 40\end{array}$ & $\begin{array}{l}29 \pm 5.4 \\
18 \pm 2.6\end{array}$ & $\begin{array}{l}34 / 36 \\
36 / 36\end{array}$ & $\begin{array}{l}36 / 36 \\
34 / 36\end{array}$ \\
\hline Bilehjani, 2009 & Iran & 80 & Normal & $\begin{array}{l}\text { MCL } \\
\text { GVL }\end{array}$ & ETT & $\begin{array}{l}29 / 40 \\
35 / 40\end{array}$ & $\mathrm{~N} / \mathrm{A}$ & $\mathrm{N} / \mathrm{A}$ & $\mathrm{N} / \mathrm{A}$ \\
\hline Blajic, 2019 & Slovenia & 178 & All & $\begin{array}{c}\text { MCL } \\
\text { CM } \\
\text { KV }\end{array}$ & $\begin{array}{c}\text { ETT } \\
(6.5 \mathrm{~mm})\end{array}$ & $\begin{array}{l}56 / 59 \\
59 / 60 \\
56 / 59\end{array}$ & $\begin{array}{c}29 \pm 14 \\
25 \pm 7 \\
29 \pm 9\end{array}$ & $\begin{array}{l}52 / 59 \\
55 / 60 \\
57 / 59\end{array}$ & $\mathrm{~N} / \mathrm{A}$ \\
\hline Bruck, 2015 & Germany & 56 & Difficult & $\begin{array}{l}\text { CM } \\
\text { GVL }\end{array}$ & $\begin{array}{c}\text { ETT } \\
(7.5 / 8 \mathrm{~mm})\end{array}$ & $\begin{array}{l}15 / 26 \\
28 / 30\end{array}$ & $\mathrm{~N} / \mathrm{A}$ & $\begin{array}{l}26 / 26 \\
30 / 30\end{array}$ & $\begin{array}{c}9 / 26 \\
12 / 30\end{array}$ \\
\hline Caparlar, 2019 & Turkey & 78 & Normal & $\begin{array}{c}\text { MCL } \\
\text { CM }\end{array}$ & ETT & $\mathrm{N} / \mathrm{A}$ & $\begin{array}{c}41.49 \pm 10.3 \\
27.74 \pm 7.2\end{array}$ & $\begin{array}{l}39 / 39 \\
39 / 39\end{array}$ & $\begin{array}{l}0 / 39 \\
0 / 39\end{array}$ \\
\hline Cavus, 2011 & Germany & 87 & All & $\begin{array}{c}\text { MCL } \\
\text { CM }\end{array}$ & ETT & $\begin{array}{l}48 / 50 \\
27 / 37\end{array}$ & $\mathrm{~N} / \mathrm{A}$ & $\mathrm{N} / \mathrm{A}$ & $\mathrm{N} / \mathrm{A}$ \\
\hline Chalkeidis, 2010 & Greece & 63 & All & $\begin{array}{l}\text { MCL } \\
\text { ATQ }\end{array}$ & ETT & $\begin{array}{l}27 / 28 \\
31 / 35\end{array}$ & $\mathrm{~N} / \mathrm{A}$ & $\mathrm{N} / \mathrm{A}$ & $\mathrm{N} / \mathrm{A}$ \\
\hline Chandrashek-araiah, 2017 & Bahrain & 60 & Difficult & $\begin{array}{l}\mathrm{MCL} \\
\mathrm{CM}\end{array}$ & ETT & $\mathrm{N} / \mathrm{A}$ & $\mathrm{N} / \mathrm{A}$ & $\begin{array}{l}26 / 30 \\
28 / 30\end{array}$ & $\mathrm{~N} / \mathrm{A}$ \\
\hline Dhonneur, 2009 & France & 212 & Difficult & $\begin{array}{l}\text { MCL } \\
\text { ATQ }\end{array}$ & ETT & $\mathrm{N} / \mathrm{A}$ & $\mathrm{N} / \mathrm{A}$ & $\begin{array}{c}90 / 106 \\
106 / 106\end{array}$ & $\mathrm{~N} / \mathrm{A}$ \\
\hline ElTahan, 2017 & Saudi Arabia & 29 & Normal & $\begin{array}{c}\mathrm{MCL} \\
\mathrm{KV}\end{array}$ & ETT & $\begin{array}{l}29 / 29 \\
29 / 29\end{array}$ & $\mathrm{~N} / \mathrm{A}$ & $\mathrm{N} / \mathrm{A}$ & $\mathrm{N} / \mathrm{A}$ \\
\hline
\end{tabular}


Table 1. Cont.

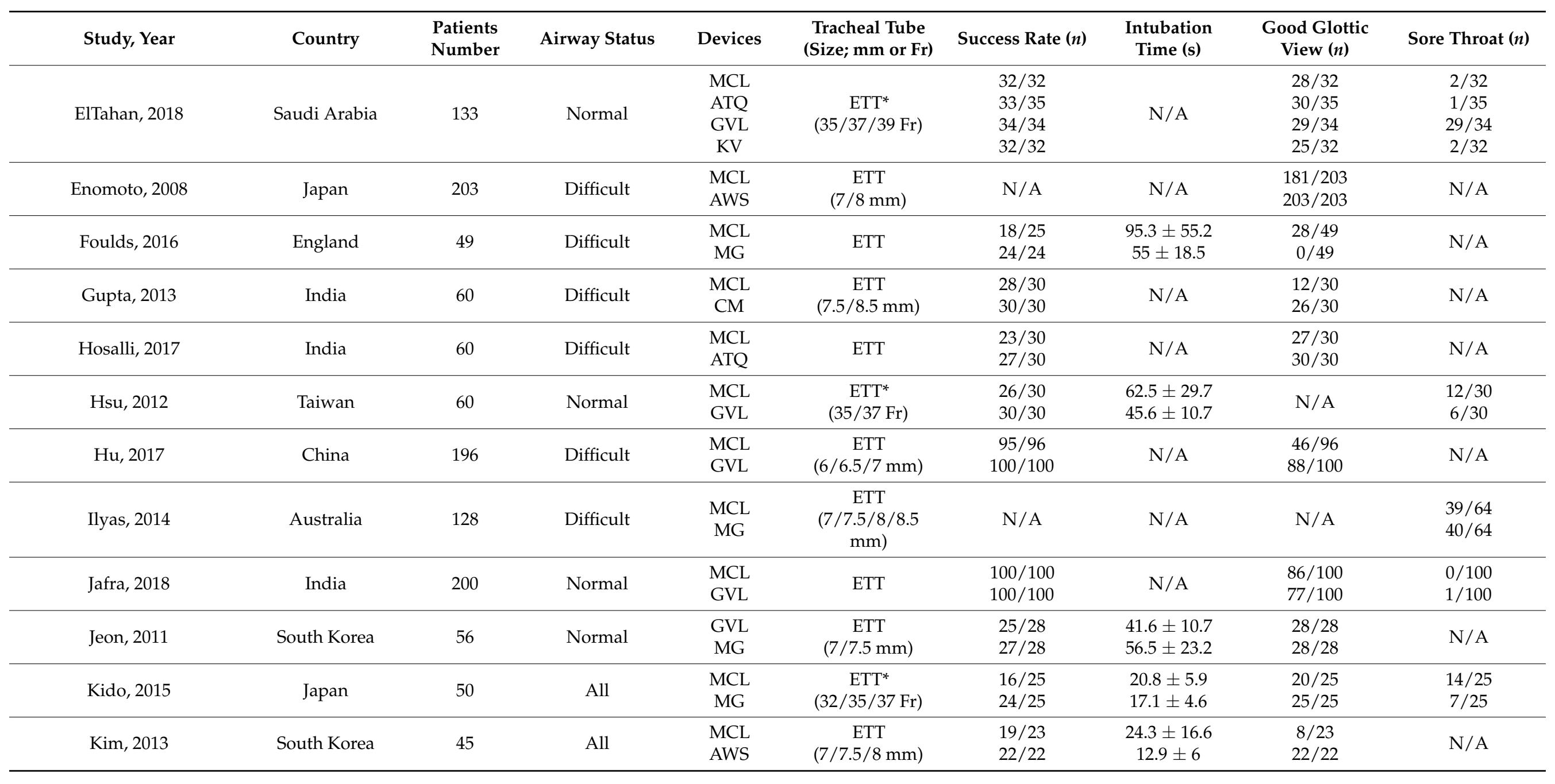


Table 1. Cont.

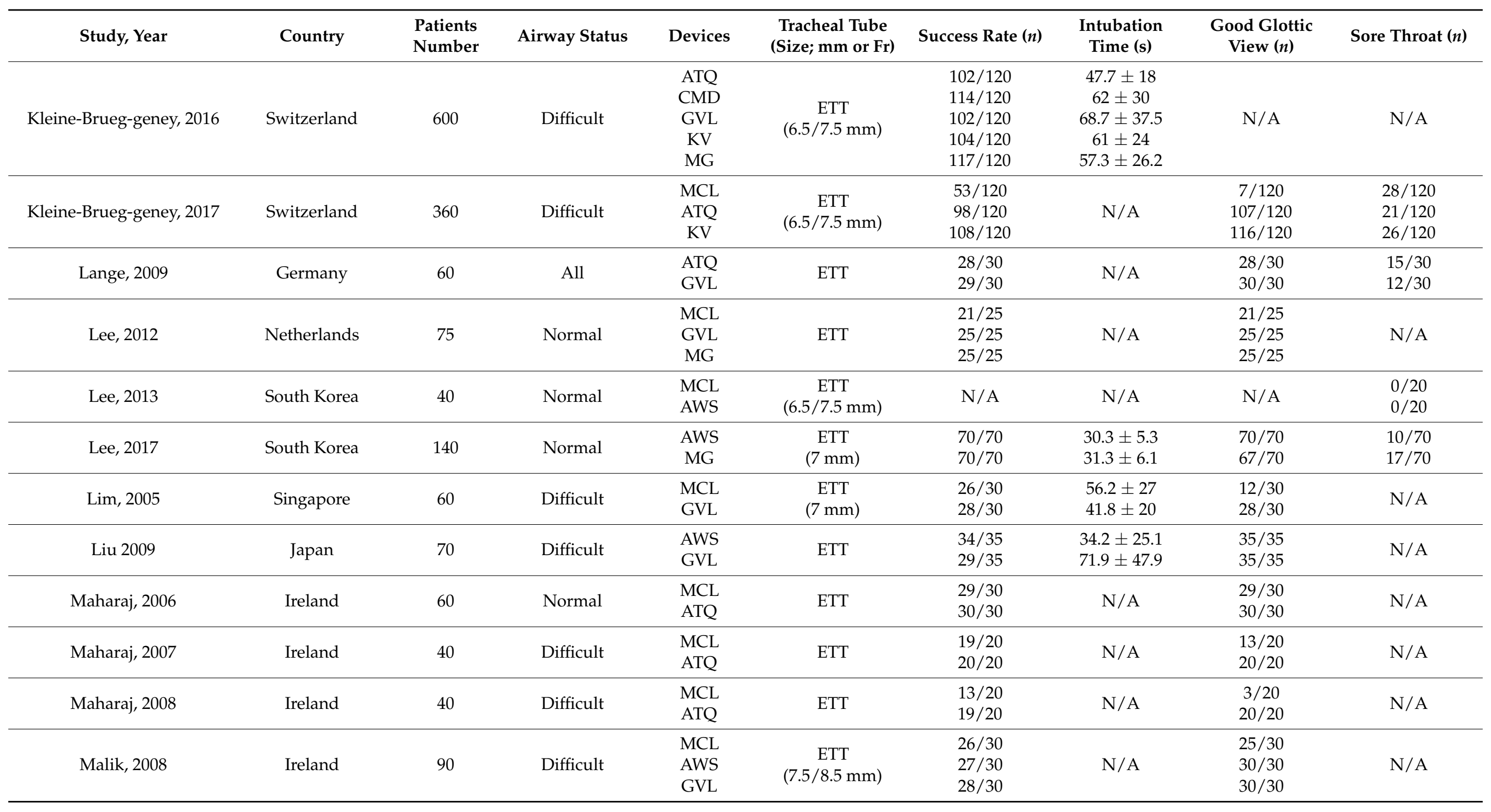


Table 1. Cont.

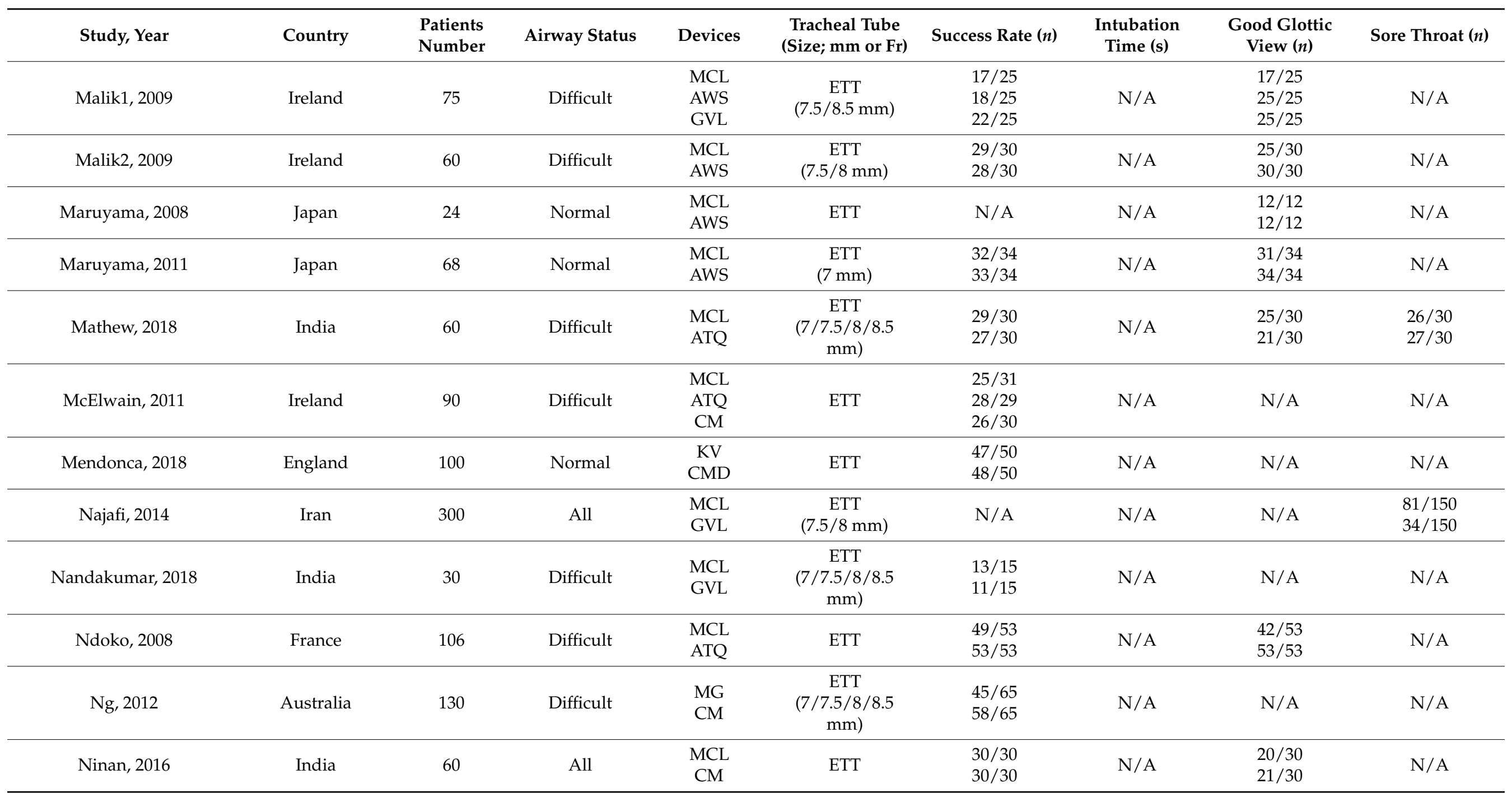


Table 1. Cont.

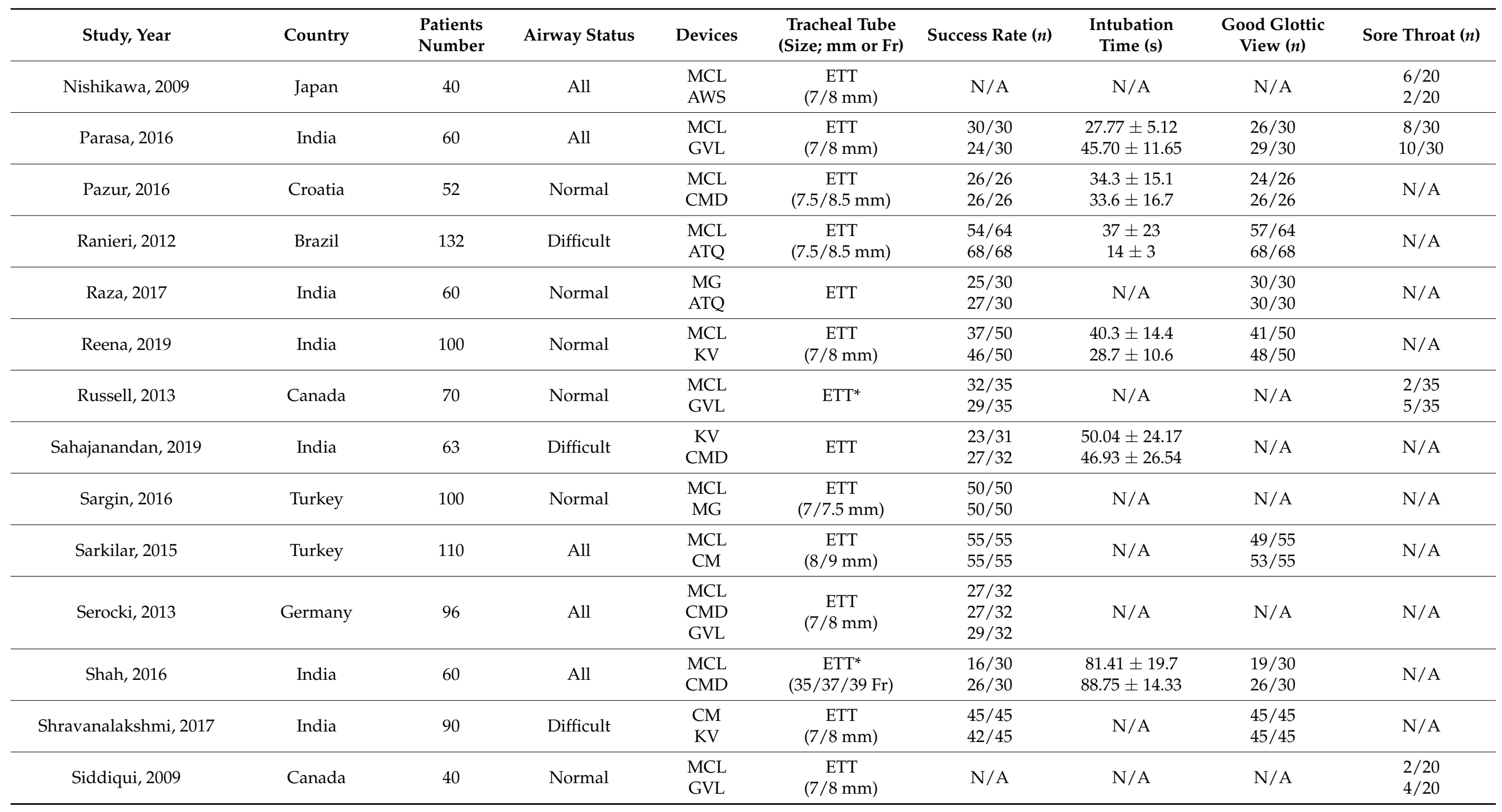


Table 1. Cont.

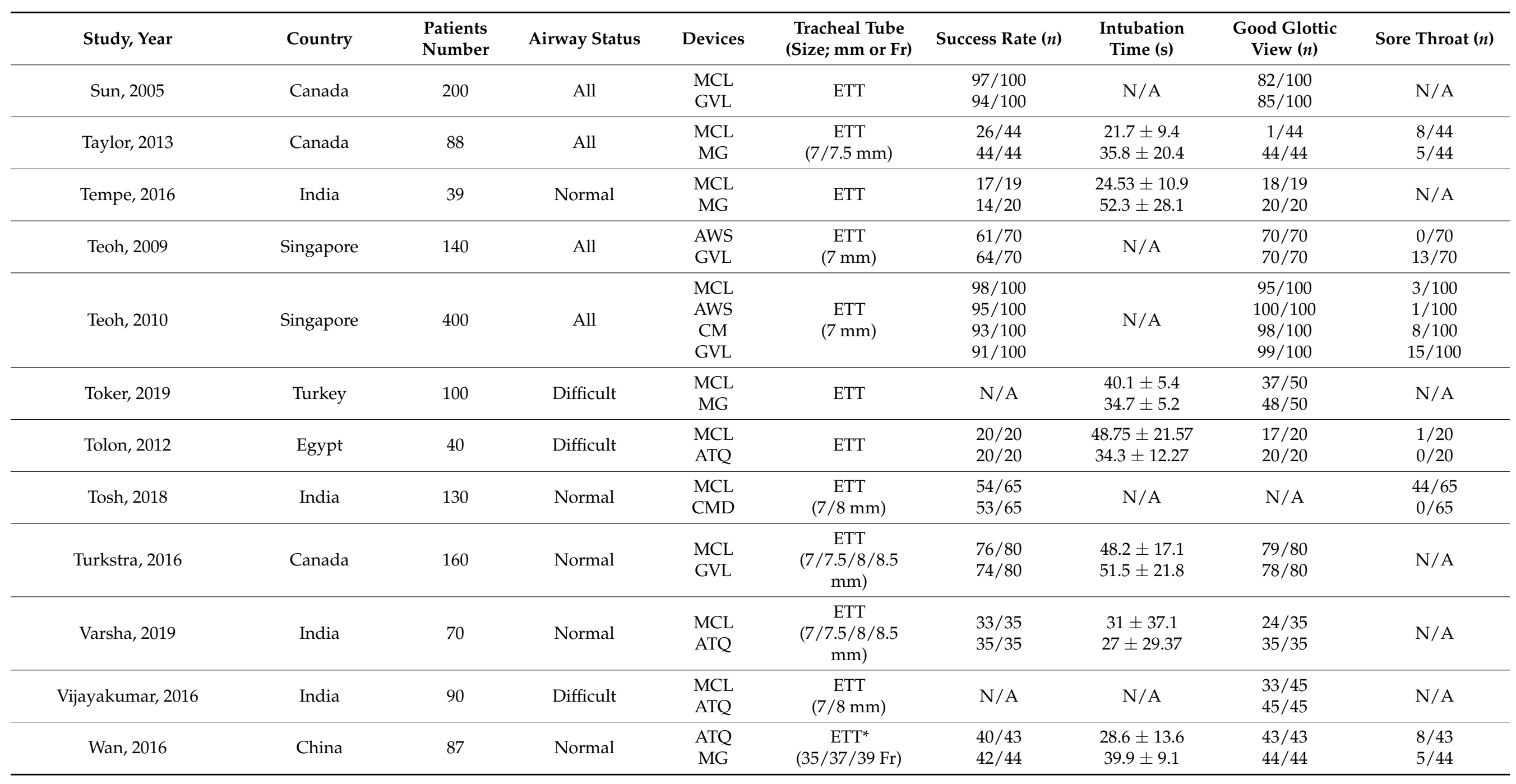


Table 1. Cont.

\begin{tabular}{|c|c|c|c|c|c|c|c|c|c|}
\hline Study, Year & Country & $\begin{array}{l}\text { Patients } \\
\text { Number }\end{array}$ & Airway Status & Devices & $\begin{array}{l}\text { Tracheal Tube } \\
\text { (Size; mm or Fr) }\end{array}$ & Success Rate (n) & $\begin{array}{l}\text { Intubation } \\
\text { Time (s) }\end{array}$ & $\begin{array}{l}\text { Good Glottic } \\
\text { View }(n)\end{array}$ & Sore Throat $(n)$ \\
\hline Wasem, 2013 & Germany & 60 & All & $\begin{array}{l}\text { MCL } \\
\text { ATQ }\end{array}$ & $\begin{array}{c}\text { ETT }^{*} \\
(35 / 37 / 39 / 41 \\
\text { Fr })\end{array}$ & $\begin{array}{l}26 / 30 \\
28 / 30\end{array}$ & $\mathrm{~N} / \mathrm{A}$ & $\begin{array}{l}30 / 30 \\
30 / 30\end{array}$ & $\begin{array}{l}6 / 30 \\
7 / 30\end{array}$ \\
\hline Wasinwong, 2017 & Thailand & 46 & Difficult & $\begin{array}{l}\text { MCL } \\
\text { GVL }\end{array}$ & $\begin{array}{c}\text { ETT } \\
(7.5 / 8 \mathrm{~mm})\end{array}$ & $\begin{array}{l}21 / 23 \\
23 / 23\end{array}$ & $\mathrm{~N} / \mathrm{A}$ & $\mathrm{N} / \mathrm{A}$ & $\mathrm{N} / \mathrm{A}$ \\
\hline Woo, 2012 & South Korea & 159 & All & $\begin{array}{l}\text { MCL } \\
\text { AWS }\end{array}$ & $\begin{array}{c}\text { ETT } \\
(7 / 8 \mathrm{~mm})\end{array}$ & $\begin{array}{c}50 / 109 \\
50 / 50\end{array}$ & $\mathrm{~N} / \mathrm{A}$ & $\mathrm{N} / \mathrm{A}$ & $\begin{array}{c}26 / 109 \\
29 / 50\end{array}$ \\
\hline Xue, 2007 & China & 57 & Difficult & $\begin{array}{l}\text { MCL } \\
\text { GVL }\end{array}$ & $\begin{array}{c}\text { ETT } \\
(7 / 7.5 \mathrm{~mm})\end{array}$ & $\begin{array}{l}27 / 27 \\
28 / 30\end{array}$ & $\mathrm{~N} / \mathrm{A}$ & $\mathrm{N} / \mathrm{A}$ & $\mathrm{N} / \mathrm{A}$ \\
\hline Yao, 2015 & China & 96 & All & $\begin{array}{l}\text { MCL } \\
\text { MG }\end{array}$ & $\begin{array}{c}\text { ETT }^{*} \\
(35 / 37 / 39 \mathrm{Fr})\end{array}$ & $\begin{array}{l}48 / 48 \\
48 / 48\end{array}$ & $\begin{array}{c}24.3 \pm 7.1 \\
29.7 \pm 10.5\end{array}$ & $\begin{array}{l}48 / 48 \\
48 / 48\end{array}$ & $\begin{array}{l}6 / 48 \\
8 / 48\end{array}$ \\
\hline Yi, 2015 & China & 70 & Normal & $\begin{array}{l}\text { ATQ } \\
\text { GVL }\end{array}$ & $\begin{array}{c}\text { ETT }^{*} \\
(35 / 37 / 39 \mathrm{Fr})\end{array}$ & $\begin{array}{l}33 / 35 \\
34 / 35\end{array}$ & $\mathrm{~N} / \mathrm{A}$ & $\begin{array}{l}28 / 35 \\
35 / 35\end{array}$ & $\begin{array}{l}6 / 35 \\
8 / 35\end{array}$ \\
\hline Yoo, 2018 & Korea & 44 & Difficult & $\begin{array}{l}\text { MCL } \\
\text { MG }\end{array}$ & $\begin{array}{c}\text { ETT }^{*} \\
(35 / 37 \text { Fr })\end{array}$ & $\begin{array}{l}17 / 22 \\
21 / 22\end{array}$ & $\begin{array}{c}52.7 \pm 11.1 \\
45 \pm 11.1\end{array}$ & $\begin{array}{l}12 / 22 \\
21 / 22\end{array}$ & $\mathrm{~N} / \mathrm{A}$ \\
\hline Yumul, 2016 & USA & 60 & Difficult & $\begin{array}{l}\text { GVL } \\
\text { MG }\end{array}$ & ETT & $\begin{array}{l}28 / 30 \\
21 / 30\end{array}$ & $\begin{array}{l}69 \pm 34 \\
62 \pm 31\end{array}$ & $\begin{array}{l}28 / 30 \\
30 / 30\end{array}$ & $\begin{array}{c}7 / 30 \\
11 / 30\end{array}$ \\
\hline
\end{tabular}

ETT, Endotracheal tube; ETT*, the use of double-lumen endotracheal tube in open thoracic surgery; Fr, French(scale); N/A, Not applicable; MCL, Macintosh laryngoscope; ATQ, Airtraq AWS, Airwayscope; CM, C-MAC; CMD, C-MAC d-blade; GVL, GlideScope; KV, King Vision; MG, McGrath. 


\subsection{Quality Assessment of the Included Studies}

The results of the quality assessments of the included studies are presented in Figure S1. All studies showed a high risk of bias in the two domains for blinding of participants and personnel (performance bias) or outcome assessors (detection bias). Most studies showed low or unclear risk of bias in four domains: random sequence generation, allocation concealment, incomplete outcome data, and selective reporting. Only two studies showed a high risk of bias among these four domains. The study by Sarkilar in 2015 was identified as a high risk of bias in random sequence generation due to a time interval of more than one week in the randomization between the MCL and C-MAC groups. Additionally, the study by Cavus in 2011 showed a high risk of bias for incomplete outcome data in the C-MAC group.

\subsection{Quantitative Data Synthesis}

\subsubsection{Intubation Success Rate at First Attempt (Success)}

In the rank analysis using SUCRA, CMD was the overall most successful VL (SUCRA 77.7) and in the context of difficult airway (SUCRA 85.2) status. The pooled success rates of CMD were $90.6 \%$ (358/395 patients) in the all airway status category (the range of success rate $=81-100 \%$ in eight included studies) $[13,29,61,78,89,92,93,103]$ and $92.7 \%$ (178/192 patients) in the difficult airway status category (the range of success rate $=92-95 \%$ in three included studies) $[29,61,89]$. In the normal airway status category, King Vision was the most successful (SUCRA 72.7), and the pooled success rate of King Vision was $92 \%$ (169/183 patients; the range of success rate $=68-100 \%$ in five included studies) $[30,47,48,78,88]$ (Figures 3-5). The success rates in all airway were ranked as follows based on SUCRA values (\%); CMD 77.7 (highest), McGrath 76.6, King Vision 67.5, C-MAC 50.9, Airtraq 49.4, GlideScope 48.6, Airwayscope 20.8, MCL 8.6 (lowest). The success rate in normal airway was ranked as follows; King Vision 72.7 (highest), GlideScope 65.9, Airwayscope 60.4, C-MAC 52.0, CMD 48.1, McGrath 42.8, MCL 32.6, Airtraq 25.6 (lowest). The success rates in difficult airway were ranked as follows; CMD 85.2 (highest), McGrath 68.0, C-MAC 64.7, King Vision 58.7, Airtraq 54.9, GlideScope 47.5, Airwayscope 15.9, MCL 4.9 (lowest).

\subsubsection{Intubation Time to Confirmation by Capnometry (Speed)}

In the rank analysis using SUCRA, C-MAC was the fastest VL in the context of all (SUCRA 84.9) and normal (SUCRA 84.7) airway status. The intubation time of C-MAC ranged from 25 to $32 \mathrm{~s}(25 \pm 7 \mathrm{~s}$ vs. $27 \pm 7 \mathrm{~s}$ vs. $32 \pm 6 \mathrm{~s}$; resulted from 144 patients in three included studies) [28,41,116] in all airway status and $27 \mathrm{~s}$ (27 $\pm 7 \mathrm{~s}$; resulting from 39 patients in one included study) [42] in normal airway status category. In the difficult airway condition, the Airwayscope was the fastest (SUCRA 88.7). The intubation time of the Airwayscope was $34 \mathrm{~s}$ ( $34 \pm 25 \mathrm{~s}$; resulting from 35 patients in one included study) [67] (Figures 3-5). The intubation time in all airway was ranked as follows based on SUCRA values (\%); C-MAC 84.9 (highest), Airwayscope 70.4, Airtraq 65.7, King Vision 54.9, CMD 47.4, MCL 31.8, GlideScope 30.9, McGrath 14.1 (lowest). The intubation time in normal airway was ranked as follows; C-MAC 84.7 (highest), GlideScope 59.5, King Vision 54.7, Airtraq 50.6, CMD 49.7, MCL 48.4 (lowest). The intubation time in difficult airway was ranked as follows; Airwayscope 88.7 (highest), Airtraq 79.8, CMD 71.7, King Vision 51.7, C-MAC 41.3, McGrath 40.3, GlideScope 25.8, MCL 0.7 (lowest). 
(A)

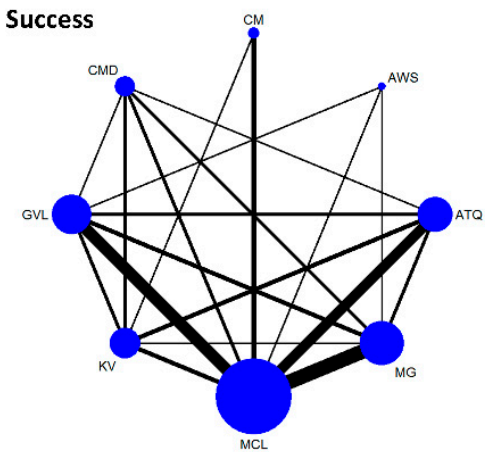

Safety

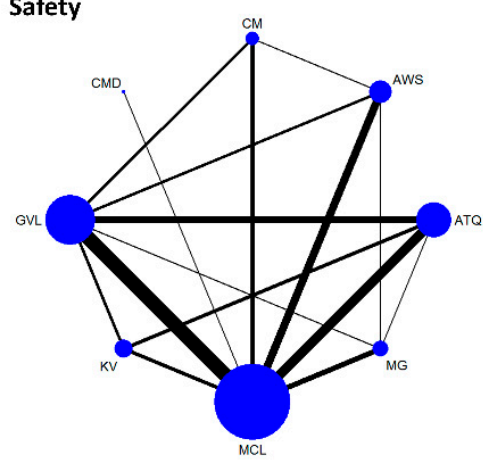

(B)

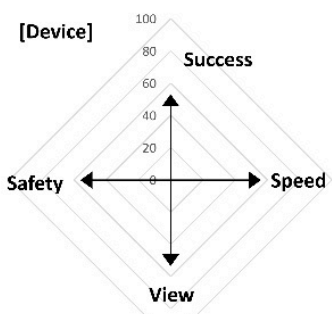

AWS

MCL

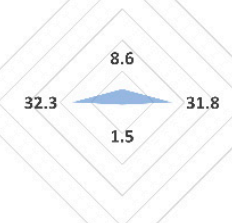

CM

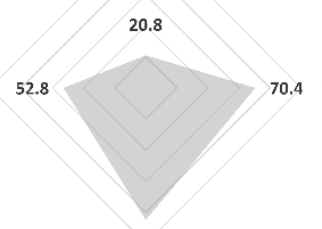

GVL

84.9

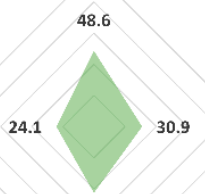

42.6

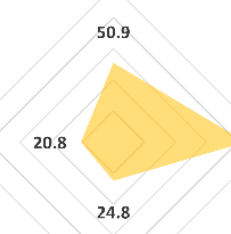

KV

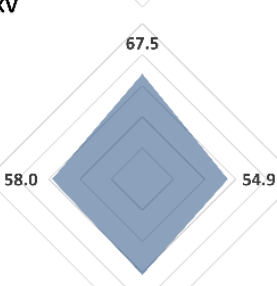

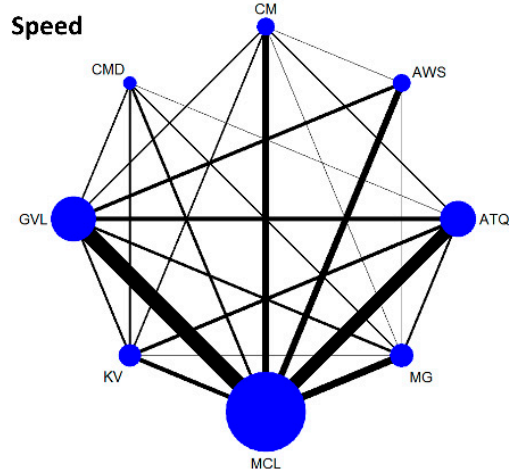

View

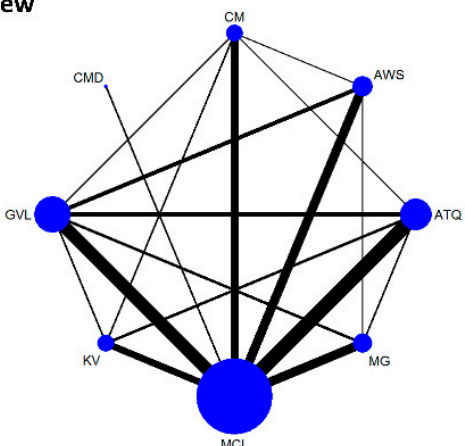

ATQ

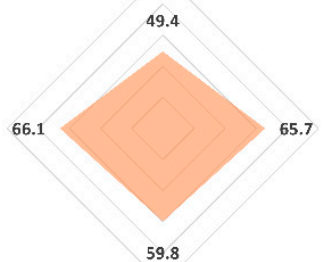

CMD $\quad 77.7$

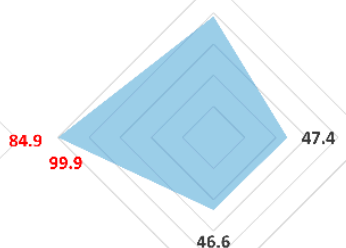

MG

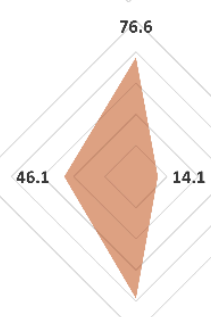

Figure 3. Comparison of efficacy and safety for intubation using video laryngoscopes in all circumstances of airway. (A) Network maps for the successful, speedy and good glottic view at first intubation attempt (efficacy), and sore throat within $24 \mathrm{~h}$ after extubation (safety). (B) Radar charts using the surface under the cumulative ranking (SUCRA) for efficacy and safety in each video laryngoscope. The highest value of SUCRA for each outcome was marked in red. MCL, Macintosh direct laryngoscope; ATQ, Airtraq video laryngoscope; AWS, Pentax Airwayscope; CM, C-MAC video laryngoscope; CMD, C-MAC D-Blade video laryngoscope; GVL, GlideScope; KV, King Vision video laryngoscope; MG, McGrath video laryngoscope. 
(A) Success

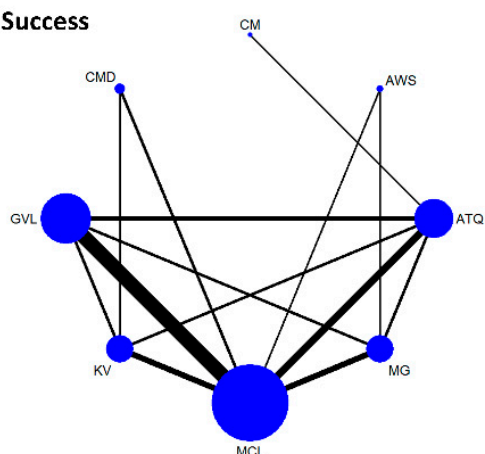

ssitey

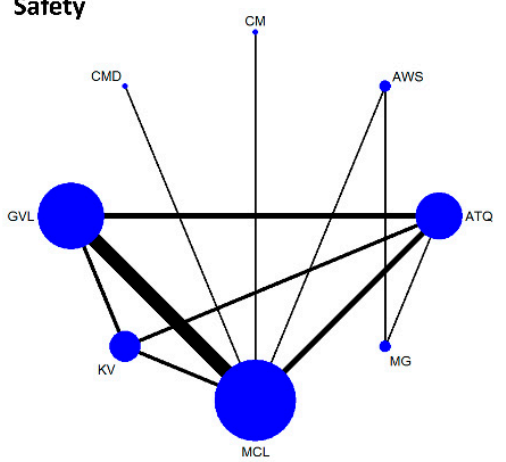

(B)

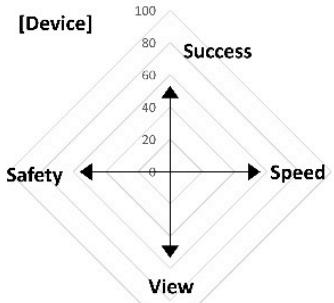

Aws

60.4

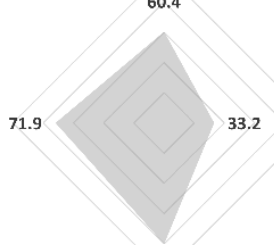

GVL

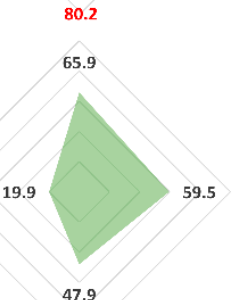

Ma

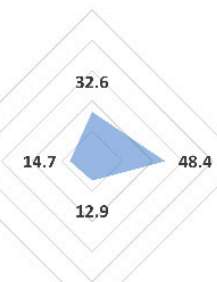

CM

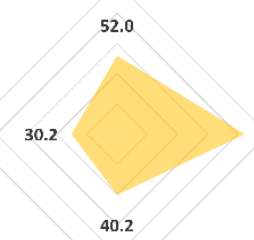

KV

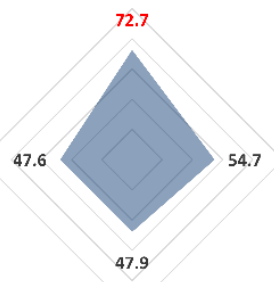

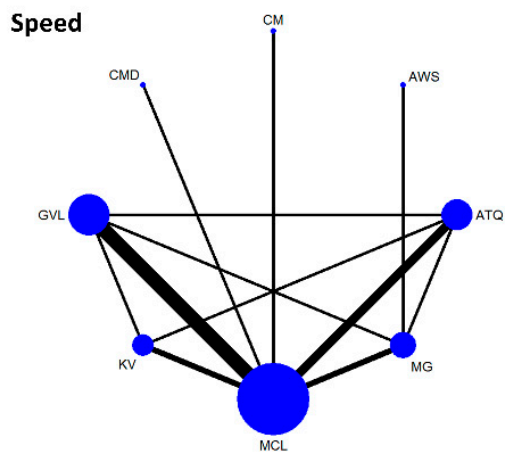

View

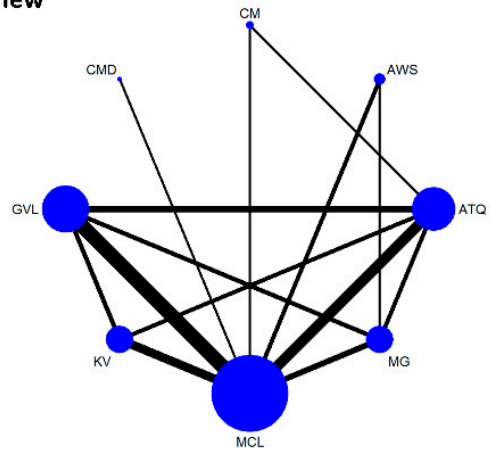

ATQ

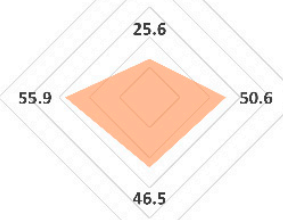

CMD

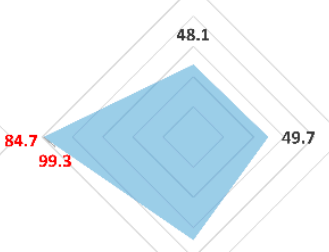

MG

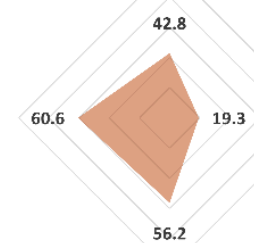

Figure 4. Comparison of efficacy and safety for intubation using video laryngoscopes in normal airway. (A) Network maps for the successful, speedy and good glottic view at first intubation attempt (efficacy), and sore throat within $24 \mathrm{~h}$ after extubation (safety). (B) Radar charts using the surface under the cumulative ranking (SUCRA) for efficacy and safety in each video laryngoscope. The highest value of SUCRA for each outcome was marked in red. MCL, Macintosh direct laryngoscope; ATQ, Airtraq video laryngoscope; AWS, Pentax Airwayscope; CM, C-MAC video laryngoscope; CMD, C-MAC D-Blade video laryngoscope; GVL, GlideScope; KV, King Vision video laryngoscope; MG, McGrath video laryngoscope. 
(A) Success

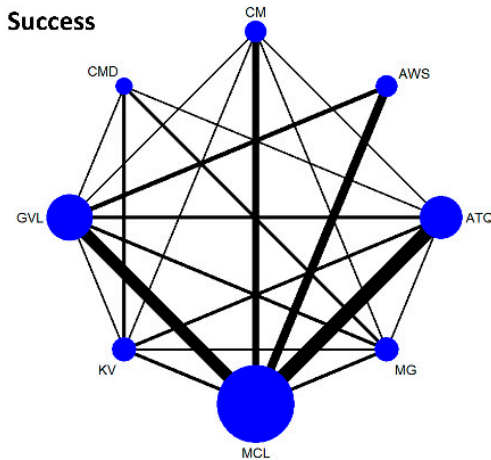

Safety

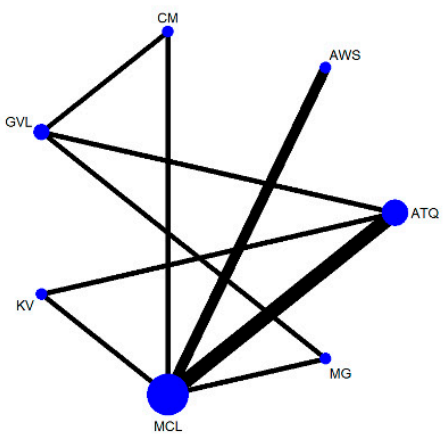

Speed

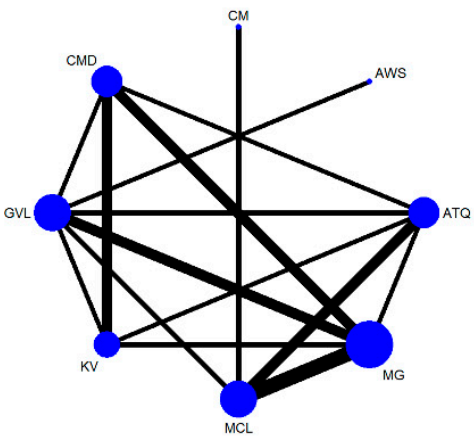

View

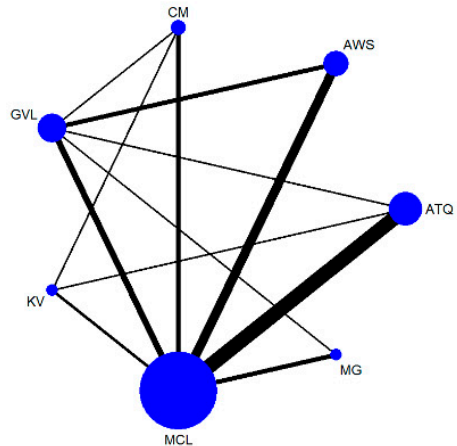

ATQ

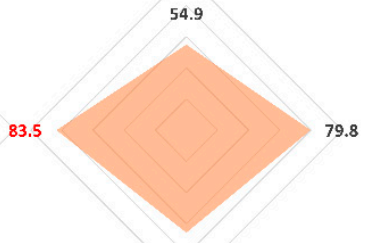

65.7

CMD

85.2
AW

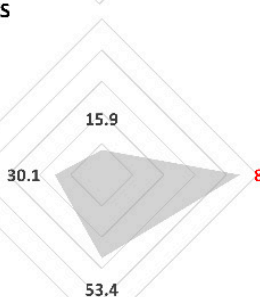

GVL

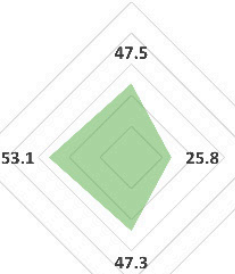

CM

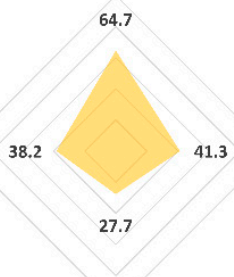

KV

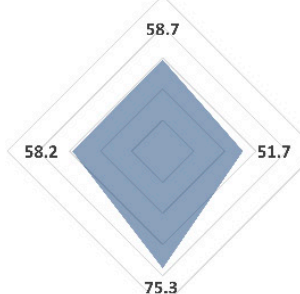

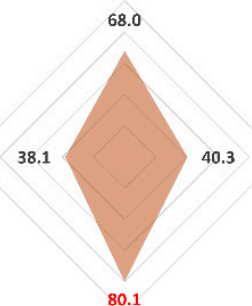

Figure 5. Comparison of efficacy and safety for intubation using video laryngoscopes in difficult airway. (A) Network maps for the successful, speedy and good glottic view at first intubation attempt (efficacy), and sore throat within $24 \mathrm{~h}$ after extubation (safety). (B) Radar charts using the surface under the cumulative ranking (SUCRA) for efficacy and safety in each video laryngoscope. The highest value of SUCRA for each outcome was marked in red. MCL, Macintosh direct laryngoscope; ATQ, Airtraq video laryngoscope; AWS, Pentax Airwayscope; CM, C-MAC video laryngoscope; CMD, C-MAC D-Blade video laryngoscope; GVL, GlideScope; KV, King Vision video laryngoscope; MG, McGrath video laryngoscope. * lack of study. 


\subsubsection{Glottic View (View)}

In the rank analysis using SUCRA, Airwayscope showed the best glottic view (SUCRA 84.9) in the normal airway status category (SUCRA 80.2). The pooled rate of good glottic view were $98 \%$ (692/699 patients; the range of good glottic view $=86-100 \%$ in 13 included studies) $[9,35,49,59,64,67,71-74,99,100,116]$ in all airway status and $100 \%$ $(116 / 116$ patients in three included studies) $[64,74,116]$ in the normal airway status category. In the difficult airway status category, McGrath was best in glottic view (SUCRA 84.9), and the pooled rate of good glottic view was $98 \%$ (148/151 patients resulted from four included studies) $[50,101,114,115]$ (Figures 3-5). When sorting by rank, glottic view ranking in all airway based on SUCRA values, from best to worst, were as follows; Airwayscope 84.9, McGrath 78.3, King Vision 61.6, Airtraq 59.8, CMD 46.6, GlideScope 42.6, C-MAC 24.8, MCL 1.5. Glottic view ranking in normal airway based on SUCRA values, from best to worst, were as follows; Airwayscope 80.2, CMD 68.2, McGrath 56.2, GlideScope 47.9 = King Vision 47.9, Airtraq 46.5, C-MAC 40.2, MCL 12.9. Glottic view ranking in difficult airway based on SUCRA values, from best to worst, were as follows; McGrath 80.1, King Vision 75.3, Airtraq 65.7, Airwayscope 53.4, GlideScope 47.3, C-MAC 27.7, MCL 0.4.

\subsubsection{Sore Throat within $24 \mathrm{~h}$ after Extubation (Safety)}

In the rank analysis using SUCRA, CMD showed the lowest incidence of sore throat within $24 \mathrm{~h}$ after extubation in all (SUCRA 99.9) and normal (SUCRA 99.3) airway status categories. The pooled incidence of sore throat for CMD was $0 \%(0 / 65$ patients resulted from one included study) in both airway status categories [103]. In the difficult airway status category, Airtraq also showed a low incidence of sore throat (SUCRA 83.5). The pooled incidence rate of sore throat in Airtraq was 12.6\% (26/206 patients; the range of incidence $=0-17.5 \%$ in four included studies) $[39,60,76,102]$ (Figures 3-5). When sorting by rank, safety ranking in all airway based on SUCRA values were as follows; CMD 99.9, Airtraq 66.1, King Vision 58.0, Airwayscope 52.8, McGrath 46.1, MCL 32.3, GlideScope 24.1, C-MAC 20.8. Safety ranking in normal airway were as follows; CMD 99.3, Airwayscope 71.9, McGrath 60.6, Airtraq 55.9, King Vision 47.6, C-MAC 30.2, GlideScope 19.9, MCL 14.7. Safety ranking in difficult airway were as follows; Airtraq 83.5, King Vision 58.2, GlideScope 53.1, MCL 48.8, C-MAC 38.2, McGrath 38.1, Airwayscope 30.1.

\subsection{Quality Evidence in GRADE Assessment}

The evidence level of each comparison between VL and MCL or intercomparison of the VLs is fully described in Table S1. We extracted and summarized the comparisons of all moderate certainty of evidence assessed by the GRADE tool in Table 2.

For intubation success, five VLs (Airtraq, CMD, GlideScope, King Vision, and McGrath) were more successful than MCL. Moderate evidence did not exist in the intercomparison of VLs. For intubation time, four VLs (Airwayscope, C-MAC, GlideScope, and McGrath) were faster than MCL. In the intercomparison of VLs, the Airtraq was faster than other VLs (CMD, GlideScope, King Vision in difficult airway, and McGrath). The Airwayscope was also faster than GlideScope. However, GlideScope was faster than McGrath and King Vision in the normal airway category, whereas it was slower than McGrath in the difficult airway category. For the glottic view, Airtraq and Airwayscope showed better glottic views than MCL. No moderate evidence existed in the intercomparison of VLs for the glottic view. For safety after extubation, three VLs (Airtraq, C-MAC, and CMD) showed a lower incidence of sore throat than MCL. Moreover, two VLs (Airtraq and McGrath) showed a lower incidence of sore throat than GlideScope in the intercomparisons of VLs.

\subsection{Publication Bias}

In the comparison-adjusted funnel plot, most funnel plots showed symmetry for the success, speed, view, and safety in three airway status categories (all vs. normal vs. difficult). Asymmetry was only observed in sore throat (safety) in all, normal, and difficult airway categories, which suggested the presence of small-study effects (Figures S2-S4). 
Table 2. Moderate certainty of evidence of comparison between VL and MCL or intercomparison of VLs.

\begin{tabular}{|c|c|c|c|c|c|c|c|c|c|}
\hline & \multirow[b]{2}{*}{$\begin{array}{l}\text { Participants } \\
\text { (Studies) }\end{array}$} & \multirow[b]{2}{*}{ Intervention } & \multirow[b]{2}{*}{ Comparison } & \multirow[b]{2}{*}{ Airway Status } & \multicolumn{2}{|c|}{ Study Event Rates (\%) } & \multirow[b]{2}{*}{$\begin{array}{l}\text { Relative Effect } \\
\quad(95 \% \mathrm{CI})\end{array}$} & \multicolumn{2}{|c|}{ Anticipated Absolute Effects } \\
\hline & & & & & Comparison & Intervention & & $\begin{array}{l}\text { Risk with } \\
\text { Comparison }\end{array}$ & $\begin{array}{c}\text { Risk Difference with } \\
\text { Intervention }\end{array}$ \\
\hline \multirow{7}{*}{ Success } & $\begin{array}{c}778 \\
\text { (9 RCTs) }\end{array}$ & ATQ & MCL & Difficult & $\begin{array}{l}285 / 388 \\
(73.5 \%)\end{array}$ & $\begin{array}{l}360 / 390 \\
(92.3 \%)\end{array}$ & $\begin{array}{c}\text { OR } 3.06 \\
(1.39 \text { to } 6.72)\end{array}$ & 735 per 1000 & $\begin{array}{c}160 \text { more per } 1000 \\
\text { (from } 59 \text { more to } 214 \text { more) }\end{array}$ \\
\hline & $\begin{array}{c}684 \\
(7 \mathrm{RCTs})\end{array}$ & KV & MCL & All & $\begin{array}{c}250 / 342 \\
(73.1 \%)\end{array}$ & $\begin{array}{c}315 / 342 \\
(92.1 \%)\end{array}$ & $\begin{array}{c}\text { OR } 2.01 \\
\text { (1.01 to } 4.01)\end{array}$ & 731 per 1000 & $\begin{array}{c}114 \text { more per } 1000 \\
\text { (from } 2 \text { more to } 185 \text { more) }\end{array}$ \\
\hline & $\begin{array}{c}300 \\
(2 \mathrm{RCTs})\end{array}$ & KV & MCL & Difficult & $\begin{array}{l}80 / 150 \\
(53.3 \%)\end{array}$ & $\begin{array}{l}137 / 150 \\
(91.3 \%)\end{array}$ & $\begin{array}{c}\text { OR } 3.31 \\
(1.14 \text { to } 9.56)\end{array}$ & 533 per 1000 & $\begin{array}{l}258 \text { more per } 1000 \\
\text { (from } 32 \text { more to } 383 \text { more) }\end{array}$ \\
\hline & $\begin{array}{c}306 \\
(4 \mathrm{RCTs})\end{array}$ & CMD & MCL & All & $\begin{array}{l}123 / 153 \\
(80.4 \%)\end{array}$ & $\begin{array}{l}132 / 153 \\
(86.3 \%)\end{array}$ & $\begin{array}{c}\text { OR } 2.36 \\
(1.06 \text { to } 5.26)\end{array}$ & 804 per 1000 & $\begin{array}{c}102 \text { more per } 1000 \\
\text { (from } 9 \text { more to } 152 \text { more) }\end{array}$ \\
\hline & $\begin{array}{c}93 \\
\text { (2 RCTs) }\end{array}$ & MCL & MG & Difficult & $\begin{array}{c}45 / 46 \\
(97.8 \%)\end{array}$ & $\begin{array}{c}35 / 47 \\
(74.5 \%)\end{array}$ & $\begin{array}{c}\text { OR } 0.25 \\
(0.08 \text { to } 0.76)\end{array}$ & 978 per 1000 & $\begin{array}{l}60 \text { fewer per } 1000 \\
\text { (from } 196 \text { fewer to } 7 \text { fewer) }\end{array}$ \\
\hline & $\begin{array}{c}1972 \\
(21 \mathrm{RCTs})\end{array}$ & GVL & MCL & All & $\begin{array}{l}918 / 990 \\
(92.7 \%)\end{array}$ & $\begin{array}{c}897 / 982 \\
(91.3 \%)\end{array}$ & $\begin{array}{c}\text { OR } 1.59 \\
(1.00 \text { to } 2.54)\end{array}$ & 927 per 1000 & $\begin{array}{c}26 \text { more per } 1000 \\
\text { (from } 0 \text { fewer to } 43 \text { more) }\end{array}$ \\
\hline & $\begin{array}{c}504 \\
(7 \mathrm{RCTs})\end{array}$ & GVL & MCL & Difficult & $\begin{array}{l}237 / 251 \\
(94.4 \%)\end{array}$ & $\begin{array}{l}240 / 253 \\
(94.9 \%)\end{array}$ & $\begin{array}{c}\text { OR } 2.68 \\
(1.23 \text { to } 5.81)\end{array}$ & 944 per 1000 & $\begin{array}{l}34 \text { more per } 1000 \\
\text { (from } 10 \text { more to } 46 \text { more) }\end{array}$ \\
\hline \multirow{7}{*}{$\begin{array}{l}\text { Intubation } \\
\text { time }\end{array}$} & $\begin{array}{c}240 \\
(1 \mathrm{RCT})\end{array}$ & ATQ & CMD & All & 120 & 120 & - & - & $\begin{array}{c}\text { SMD 0.58 SD lower } \\
\text { (0.83 lower to } 0.32 \text { lower })\end{array}$ \\
\hline & $\begin{array}{c}240 \\
(1 \mathrm{RCT})\end{array}$ & ATQ & CMD & Difficult & 120 & 120 & - & - & $\begin{array}{c}\text { SMD } 0.58 \text { SD lower } \\
\text { (0.83 lower to } 0.32 \text { lower) }\end{array}$ \\
\hline & $\begin{array}{c}43 \\
(1 \mathrm{RCT})\end{array}$ & ATQ & KV & Normal & 22 & 21 & - & - & $\begin{array}{c}\text { SMD 1.14 SD higher } \\
\text { (0.49 higher to } 1.79 \text { higher) }\end{array}$ \\
\hline & $\begin{array}{c}240 \\
(1 \mathrm{RCT})\end{array}$ & ATQ & KV & Difficult & 120 & 120 & - & - & $\begin{array}{c}\text { SMD 0.62 SD lower } \\
\text { (0.88 lower to } 0.37 \text { lower })\end{array}$ \\
\hline & $\begin{array}{c}42 \\
(1 \mathrm{RCT})\end{array}$ & ATQ & GVL & Normal & 21 & 21 & - & - & $\begin{array}{c}\text { SMD } 2.43 \text { SD higher } \\
\text { (1.62 higher to } 3.24 \text { higher) }\end{array}$ \\
\hline & $\begin{array}{c}240 \\
(1 \mathrm{RCT})\end{array}$ & ATQ & GVL & Difficult & 120 & 120 & - & - & $\begin{array}{c}\text { SMD 0.71 SD lower } \\
\text { (0.97 lower to } 0.45 \text { lower) }\end{array}$ \\
\hline & $\begin{array}{c}327 \\
\text { (2 RCTs) }\end{array}$ & ATQ & MG & All & 164 & 163 & - & - & $\begin{array}{l}\text { SMD 0.67 SD lower } \\
\text { (1.2 lower to } 0.14 \text { lower) }\end{array}$ \\
\hline
\end{tabular}


Table 2. Cont.

\begin{tabular}{|c|c|c|c|c|c|c|c|c|c|}
\hline & \multirow{2}{*}{$\begin{array}{l}\text { Participants } \\
\text { (Studies) }\end{array}$} & \multirow[b]{2}{*}{ Intervention } & \multirow[b]{2}{*}{ Comparison } & \multirow[b]{2}{*}{ Airway Status } & \multicolumn{2}{|c|}{ Study Event Rates (\%) } & \multirow[b]{2}{*}{$\begin{array}{l}\text { Relative Effect } \\
\quad(95 \% \mathrm{CI})\end{array}$} & \multicolumn{2}{|c|}{ Anticipated Absolute Effects } \\
\hline & & & & & Comparison & Intervention & & $\begin{array}{l}\text { Risk with } \\
\text { Comparison }\end{array}$ & $\begin{array}{l}\text { Risk Difference with } \\
\text { Intervention }\end{array}$ \\
\hline & $\begin{array}{c}87 \\
(1 \mathrm{RCT})\end{array}$ & ATQ & MG & Normal & 44 & 43 & - & - & $\begin{array}{c}\text { SMD 0.97 SD lower } \\
\text { (1.42 lower to } 0.52 \text { lower) }\end{array}$ \\
\hline & $\begin{array}{c}240 \\
(1 \mathrm{RCT})\end{array}$ & ATQ & MG & Difficult & 120 & 120 & - & - & $\begin{array}{c}\text { SMD 0.43 SD lower } \\
\text { (0.68 lower to } 0.17 \text { lower) }\end{array}$ \\
\hline & $\begin{array}{c}45 \\
(1 \mathrm{RCT})\end{array}$ & AWS & MCL & All & 23 & 22 & - & - & $\begin{array}{c}\text { SMD 0.89 SD lower } \\
\text { (1.5 lower to } 0.27 \text { lower) }\end{array}$ \\
\hline & $\begin{array}{c}70 \\
(1 \mathrm{RCT})\end{array}$ & AWS & GVL & All & 35 & 35 & - & - & $\begin{array}{c}\text { SMD 0.97 SD lower } \\
\text { (1.47 lower to } 0.48 \text { lower) }\end{array}$ \\
\hline & $\begin{array}{c}70 \\
(1 \mathrm{RCT})\end{array}$ & AWS & GVL & Difficult & 35 & 35 & - & - & $\begin{array}{c}\text { SMD 0.97 SD lower } \\
\text { (1.47 lower to } 0.48 \text { lower) }\end{array}$ \\
\hline & $\begin{array}{c}78 \\
(1 \mathrm{RCT})\end{array}$ & $\mathrm{CM}$ & MCL & Normal & 39 & 39 & - & - & $\begin{array}{c}\text { SMD 1.53 SD lower } \\
\text { (2.04 lower to } 1.02 \text { lower) }\end{array}$ \\
\hline & $\begin{array}{c}90 \\
(1 \mathrm{RCT})\end{array}$ & $\mathrm{CM}$ & MCL & Difficult & 45 & 45 & - & - & $\begin{array}{c}\text { SMD 0.76 SD lower } \\
\text { (1.19 lower to } 0.33 \text { lower) }\end{array}$ \\
\hline & $\begin{array}{c}56 \\
(1 \mathrm{RCT})\end{array}$ & GVL & MG & Normal & 28 & 28 & - & - & $\begin{array}{c}\text { SMD 0.81 SD lower } \\
\text { (1.36 lower to } 0.27 \text { lower) }\end{array}$ \\
\hline & $\begin{array}{c}300 \\
(2 \mathrm{RCTs})\end{array}$ & GVL & MG & Difficult & 150 & 150 & - & - & $\begin{array}{c}\text { SMD } 0.32 \text { SD higher } \\
\text { (0.1 higher to } 0.55 \text { higher) }\end{array}$ \\
\hline & $\begin{array}{c}193 \\
\text { (3 RCTs) }\end{array}$ & MCL & MG & Difficult & 96 & 97 & - & - & $\begin{array}{c}\text { SMD } 0.92 \text { SD higher } \\
\text { (0.62 higher to } 1.22 \text { higher) }\end{array}$ \\
\hline & $\begin{array}{c}43 \\
(1 \mathrm{RCT})\end{array}$ & GVL & KV & Normal & 22 & 21 & - & - & $\begin{array}{c}\text { SMD 0.82 SD lower } \\
\text { (1.44 lower to } 0.19 \text { lower) }\end{array}$ \\
\hline & $\begin{array}{c}60 \\
(1 \mathrm{RCT})\end{array}$ & GVL & MCL & Difficult & 30 & 30 & - & - & $\begin{array}{c}\text { SMD 0.6 SD lower } \\
\text { (1.12 lower to } 0.08 \text { lower) }\end{array}$ \\
\hline \multirow[t]{2}{*}{ Glottic view } & $\begin{array}{c}1400 \\
(16 \mathrm{RCTs})\end{array}$ & ATQ & MCL & All & $\begin{array}{l}492 / 697 \\
(70.6 \%)\end{array}$ & $\begin{array}{c}674 / 703 \\
(95.9 \%)\end{array}$ & $\begin{array}{c}\text { OR } 45.41 \\
(2.29 \text { to } 902.16)\end{array}$ & 706 per 1000 & $\begin{array}{l}285 \text { more per } 1000 \\
\text { (from } 140 \text { more to } \\
294 \text { more) }\end{array}$ \\
\hline & $\begin{array}{c}1014 \\
(10 \mathrm{RCTs})\end{array}$ & AWS & MCL & All & $\begin{array}{c}441 / 524 \\
(84.2 \%)\end{array}$ & $\begin{array}{l}483 / 490 \\
(98.6 \%)\end{array}$ & $\begin{array}{c}\text { OR } 8.60 \\
\text { (1.01 to } 73.79)\end{array}$ & 842 per 1000 & $\begin{array}{c}137 \text { more per } 1000 \\
\text { (from } 1 \text { more to } 156 \text { more) }\end{array}$ \\
\hline
\end{tabular}


Table 2. Cont.

\begin{tabular}{|c|c|c|c|c|c|c|c|c|c|}
\hline & \multirow{2}{*}{$\begin{array}{l}\text { Participants } \\
\text { (Studies) }\end{array}$} & \multirow[b]{2}{*}{ Intervention } & \multirow[b]{2}{*}{ Comparison } & \multirow[b]{2}{*}{ Airway Status } & \multicolumn{2}{|c|}{ Study Event Rates (\%) } & \multirow{2}{*}{$\begin{array}{l}\text { Relative Effect } \\
\quad(95 \% \text { CI })\end{array}$} & \multicolumn{2}{|c|}{ Anticipated Absolute Effects } \\
\hline & & & & & Comparison & Intervention & & $\begin{array}{l}\text { Risk with } \\
\text { Comparison }\end{array}$ & $\begin{array}{l}\text { Risk Difference with } \\
\text { Intervention }\end{array}$ \\
\hline & $\begin{array}{c}711 \\
\text { (6 RCTs) }\end{array}$ & AWS & MCL & Difficult & $\begin{array}{c}295 / 355 \\
(83.1 \%)\end{array}$ & $\begin{array}{c}349 / 356 \\
(98.0 \%)\end{array}$ & $\begin{array}{c}\text { OR } 49.84 \\
(3.97 \text { to } 626.44)\end{array}$ & 831 per 1000 & $\begin{array}{c}165 \text { more per } 1000 \\
\text { (from } 120 \text { more to } \\
169 \text { more) }\end{array}$ \\
\hline \multirow{6}{*}{ Safety } & $\begin{array}{c}313 \\
(5 \text { RCTs) }\end{array}$ & ATQ & GVL & All & $\begin{array}{l}112 / 156 \\
(71.8 \%)\end{array}$ & $\begin{array}{l}127 / 157 \\
(80.9 \%)\end{array}$ & $\begin{array}{c}\text { OR } 7.92 \\
(1.93 \text { to } 32.47)\end{array}$ & 718 per 1000 & $\begin{array}{c}235 \text { more per } 1000 \\
\text { (from } 113 \text { more to } \\
270 \text { more) }\end{array}$ \\
\hline & $\begin{array}{c}181 \\
\text { (3 RCTs) }\end{array}$ & ATQ & GVL & Normal & $\begin{array}{c}61 / 90 \\
(67.8 \%)\end{array}$ & $\begin{array}{c}78 / 91 \\
(85.7 \%)\end{array}$ & $\begin{array}{c}\text { OR } 2.78 \\
(1.13 \text { to } 6.81) \\
\end{array}$ & 678 per 1000 & $\begin{array}{l}176 \text { more per } 1000 \\
\text { (from } 26 \text { more to } 257 \text { more) }\end{array}$ \\
\hline & $\begin{array}{c}190 \\
(3 \mathrm{RCTs})\end{array}$ & ATQ & MCL & Normal & $\begin{array}{c}37 / 94 \\
(39.4 \%)\end{array}$ & $\begin{array}{c}55 / 96 \\
(57.3 \%)\end{array}$ & $\begin{array}{c}\text { OR } 3.13 \\
(1.26 \text { to } 7.80) \\
\end{array}$ & 394 per 1000 & $\begin{array}{l}277 \text { more per } 1000 \\
\text { (from } 56 \text { more to } 441 \text { more) }\end{array}$ \\
\hline & $\begin{array}{c}353 \\
\text { (3 RCTs) }\end{array}$ & $\mathrm{CM}$ & MCL & All & $\begin{array}{l}168 / 175 \\
(96.0 \%)\end{array}$ & $\begin{array}{c}162 / 178 \\
(91.0 \%)\end{array}$ & $\begin{array}{c}\text { RR } 7.49 \\
(1.62 \text { to } 34.61)\end{array}$ & 960 per 1000 & $\begin{array}{c}1000 \text { more per } 1000 \\
\text { (from } 595 \text { more to } \\
1000 \text { more) }\end{array}$ \\
\hline & $\begin{array}{c}130 \\
(1 \mathrm{RCT})\end{array}$ & CMD & MCL & Normal & $\begin{array}{c}21 / 65 \\
(32.3 \%)\end{array}$ & $\begin{array}{c}65 / 65 \\
(100.0 \%)\end{array}$ & $\begin{array}{c}\text { OR } 271.14 \\
(13.2 \text { to } 5568.91)\end{array}$ & 323 per 1000 & $\begin{array}{c}669 \text { more per } 1000 \\
\text { (from } 540 \text { more to } \\
677 \text { more) }\end{array}$ \\
\hline & $\begin{array}{c}60 \\
(1 \mathrm{RCT})\end{array}$ & GVL & MG & All & $\begin{array}{c}19 / 30 \\
(63.3 \%)\end{array}$ & $\begin{array}{c}23 / 30 \\
(76.7 \%)\end{array}$ & $\begin{array}{c}\text { OR } 0.07 \\
(0.01 \text { to } 0.61)\end{array}$ & 633 per 1000 & $\begin{array}{c}525 \text { fewer per } 1000 \\
\text { (from } 616 \text { fewer to } \\
120 \text { fewer) }\end{array}$ \\
\hline
\end{tabular}

RCT, randomized controlled trial; CI, Confidence interval; OR, Odds ratio; SMD, Standardised mean difference; N/A, Not available; VL, videolaryngoscope; MCL, Macintosh laryngoscope; ATQ; Airtaq, AWS, Airwayscope; CM, C-MAC; CMD, C-MAC d-blade; GVL, GlideScope; KV, King Vision; MG, McGrath. 


\section{Discussion}

This systematic review and network meta-analysis demonstrated that the CMD was relatively successful compared with other VLs and MCL for the tracheal intubation undergoing general anesthesia in all airway circumstances. Additionally, while the KV was more successful in normal airway circumstances, the CMD was more successful in difficult airway circumstances compared with other VLs and MCL. Other VLs such as MG, GVL, AWS, and CM were top three ranked VLs for intubation success in all, normal and difficult airway circumstances. The comparisons of intubation success between VLs and MCL showed moderate certainty of evidence level, whereas the intercomparisons of VLs showed low certainty evidence.

Previous meta-analyses have provided limited evidence for the usefulness of VLs compared with MCL. De jong et al. only identified the usefulness of VLs compared with DL in critical care settings through a 2014 meta-analysis [117]. In both emergency and critical care settings, the meta-analysis for seven RCTs reported that the first-pass intubation success was not significantly improved by VLs compared with DL [118]. In the 2016 Cochrane systematic review by Lewis, the 64 included studies were composed of 61 elective surgery patients and three patients in emergency settings [18]. However, this study found that VLs mostly showed better performance than DL. We hypothesized that more widespread usage and the availability of VLs in training programs will lead to improved VL performance in clinical settings. Although this study demonstrated that VLs might reduce failed intubation in difficult airways, no evidence indicated that the use of VLs affected the time required for intubation. No evidence was provided for the outcomes for intubation in the intercomparison of VLs in these meta-analyses.

To obtain consistent results and minimize the heterogeneity in the comparison of laryngoscopes, we categorized airway circumstances (normal vs. difficult) and only included studies for intubation by experienced anesthetists in elective surgery. In emergent or critical care settings, some concerns might be raised for inaccurate or rough evaluation of airway status. Furthermore, the urgency of the situation might significantly affect the intubation time or success, especially in cases of difficult airway.

The highest-ranked VLs for outcomes were CMD (success, safety), King Vision (success), Airwayscope (speed and view), C-MAC (speed), McGrath (view), and Airtraq (safety). In this study, CMD, C-MAC, and McGrath were categorized as non-channeled VLs, whereas King Vision, Airwayscope, and Airtraq were categorized as channeled VLs. Through these results, we realized that no absolute superiority existed between non-channeled and channeled VLs. These results also inspired that the most appropriate VL should be clinically decided by considering airway circumstances and the characteristics of VLs.

The included VLs have slightly different characteristics in the blade or video screen, to aid intubation. Most channeled VLs such as Airtraq, Airwayscope, and King Vision have angulated disposable blades and direct screens combined with handles [30,68,73]. Because Airtraq has an exaggerated blade curvature $\left(90^{\circ}\right)$, a view of the glottis can be provided with minimal need for airway optimisation manoeuvres such as hyperextension [68]. Compared with Airtraq, King Vision has a wider field of view $\left(160^{\circ}\right.$ vs. $80^{\circ}$, respectively) with a similar blade curvature [30]. Non-channeled VLs such as GlideScope, C-MAC, and CMD require the use of a stylet and, with the exception of McGrath, have indirect screens $[34,43,119]$. GlideScope and C-MAC have a lesser angulated blade $\left(60^{\circ}\right.$ vs. $80^{\circ}$, respectively) than Airtraq and King Vision [28,34]. In particular, CMD has an exaggerated curvature of the distal end of the blade, which faces markedly upward [119]. As a result of the curvature of the blade components, anesthetists require less cervical spine movement.

In the analysis of intubation success in a difficult airway, we additionally found that the different experiences for specific VLs might act as a confounding factor even though experienced anesthetists were enrolled. Although the pooling success rate of intubation using King Vision was $92 \%$ in the normal airway category $(169 / 183 ; 68-100 \%$ in five included studies) $[30,47,48,78,88]$, the study by Abdulmohsen (2016) reported a very low success rate for King Vision (68\%) as well as a significantly lesser performance 
for King Vision and Airtraq (intubation >15 times: King Vision 3/25 vs. Airtraq 0/25 vs. GlideScope $20 / 25$ vs. MCL 25/25) [30]. Among the other four included studies, both Mendonca 2018 and Reena 2019 showed sufficient experience for intubation (King Vision intubation $>50$ times) $[78,88]$. However, two other studies by El-Tahan reported unclear or insufficient experience for intubation (median King Vision intubation $<12$ times), even if the reported success rate was 100\% [47,48]. Thus, the experience of intubation for King Vision might play a role as a confounder for the success rate. However, in the analysis for intubation experience in Tables S2-S4, the included studies did not report outcomes by consistent manner enough to perform meta-regression. Therefore, we only summarized the information of intubation experiences and intubators. This information suggested that most investigators have enough experiences for MCL, however, the experience for VLs was relatively insufficient compared with MCL. The difference of intubation experience between MCL and VLs should be considered in the evaluation of intubation performances of VLs.

This study has some limitations. First, some important confounders might affect the outcomes of this study. Following factors might affect the intubation performance: the different intubation experience (resident vs. attending level; working history; total intubation attempts of each device), the systemic diseases of patients such as American Society of Anesthesiologists score, the hemodynamic characteristics of patients, the use of sedatives or muscle relaxants. The size and type of ETT (double lumen vs. single lumen) might also be a contributing factor for sore throat. Non-channeled video laryngoscopes (VLs) performed better in intubation than channeled VLs, videostylets, and direct laryngoscopes, according to a prior network meta-analysis by Kim et al. 2020 [120]. We concentrated on obtaining more general findings, regardless of the lumen type or ETT size. ETT's increased size could be linked to an increase in sore throat. However, the size of ETT is an ordinary variable with a narrow range, making it an insufficient variable for meta-regression. As good eye-hand coordination is necessary for intubation using non-channeled VL compared to channeled VL, the use of a stylet in non-channeled VL may be linked to an increased risk of sore throat [121]. By causing distinct hemodynamic changes during intubation, sufficient muscular relaxation has a major impact on the ease of laryngoscopy and intubation success. Depolarizing or non-depolarizing muscle relaxants may impact the results. We summarized this information in Tables S2-S4. Further sensitivity or subgroup analysis for these possible confounders was difficult to perform in the network meta-analysis because this information was not reported by consistent manner to perform further analyses. Second, small-study effects for sore throat safety were suggested in the comparison-adjusted funnel plot. This did not indicate the presence of publication bias. It was needed to interpret carefully not to overestimate the effect of the intervention. Third, certain critical criteria for defining a difficult airway were missed. Patients' histories, complaints, clinical examinations, and lastly investigative findings all fall under this category. As a result, results from meta-analyses that have been pooled for restricted information cannot adequately reflect the clinical setting. Fourth, there is no absolute distinction between channeled (without stylet) and non-channeled (with stylet) VLs. Intubation with the ATQ, for example, may require the use of a gum elastic bougie, but intubation with the GVL, CM, or MG does not. Fifth, some risk factors that were left out of the study could be linked to the occurrence or duration of sore throat. In the literature search and full text review, the majority of the studies just stated "elective surgery" rather than addressing specific surgeries. As a result, we were unable to determine whether upper airway surgery was linked to sore throat. Other details, such as a history of previous difficult intubation or a non-infectious or infective sore throat, were not clearly indicated. Sixth, the number of attempts at intubation and cuff pressure were significant factors in the rise in intubation-related complications. We could not find any data on cuff pressure in any of the research we looked at. According to the complete text review, the number of intubation attempts ranged from one to five times. For meta-analysis, however, it was insufficient and heterogeneous to synthesize. As a result, we only used the first attempt at intubation as a primary outcome because the data 
was sufficient and homogeneous. Seventh, several intubation-related complications, as well as sore throat, were thoroughly investigated. Other mechanical complications have already been collected, such as mucosal bleeding and dental injury. As the data were insufficient and heterogeneous, we were unable to synthesize it in the network meta-analysis.

In conclusion, CMD and King Vision could be relatively successful VLs for tracheal intubation in the comparisons of MCL and other VLs under general anesthesia. The comparisons of intubation success between VLs and MCL showed moderate certainty of evidence level, whereas the intercomparisons of VLs showed low certainty evidence.

Supplementary Materials: The following are available online at https:/ / www.mdpi.com/article/10 $.3390 / j p m 12030363 /$ s1. Figure S1: Risk of bias assessment. Author's judgments about each risk of bias item for each included study, Figure S2: Comparison-adjusted funnel plot for the network metaanalysis of (A) the success at first intubation attempts, (B) intubation time, (C) glottic view and (D) sore throat in in all circumstances of airway, Figure S3: Comparison-adjusted funnel plot for the network meta-analysis of (A) the success at first intubation attempts, (B) intubation time, (C) glottic view and (D) sore throat in in normal airway, Figure S4: Comparison-adjusted funnel plot for the network metaanalysis of (A) the success at first intubation attempts, (B) intubation time, (C) glottic view and (D) sore throat in difficult airway, Table S1: The evidence level of each comparison between videolarygoscopes and Macintosh laryngoscope or intercomparison of the videolaryngoscopes; Table S2: Analysis for factors attributing outcomes according to airway circumstances in included studies; All airway, Table S3: Analysis for factors attributing outcomes according to airway circumstances in included studies; Normal airway, Table S4: Analysis for factors attributing outcomes according to airway circumstances in included studies; Difficult airway, Document S1: Search strategies by Medline, EMBASE, and the Cochrane Library databases.

Author Contributions: J.L.: writing—original draft, data curation, software; Y.C.: writing-original draft, methodology; W.K.: supervision, writing—reviewing and editing; K.-S.C.: formal analysis; B.-H.J.: validation; H.S.: data curation; C.A.: visualization; J.G.K.: data curation, formal analysis; M.K.N.: validation; T.H.L.: conceptualization; D.W.K.: conceptualization. All authors have read and agreed to the published version of the manuscript.

Funding: This research received no external funding.

Institutional Review Board Statement: Not applicable.

Informed Consent Statement: Not applicable.

Conflicts of Interest: The authors declare no conflict of interests.

\section{References}

1. Caplan, R.A.; Posner, K.L.; Ward, R.J.; Cheney, F.W. Adverse respiratory events in anesthesia: A closed claims analysis. Anesthesiology 1990, 72, 828-833. [CrossRef] [PubMed]

2. Rose, D.K.; Cohen, M.M. The airway: Problems and predictions in 18,500 patients. Can. J. Anaesth. 1994, 41, 372-383. [CrossRef]

3. Crosby, E.T.; Cooper, R.M.; Douglas, M.J.; Doyle, D.J.; Hung, O.R.; Labrecque, P.; Muir, H.; Murphy, M.F.; Preston, R.P.; Rose, D.K.; et al. The unanticipated difficult airway with recommendations for management. Can. J. Anaesth. 1998, 45, 757-776. [CrossRef]

4. Karkouti, K.; Rose, D.K.; Wigglesworth, D.; Cohen, M.M. Predicting difficult intubation: A multivariable analysis. Can. J. Anaesth 2000, 47, 730-739. [CrossRef]

5. Juvin, P.; Lavaut, E.; Dupont, H.; Lefevre, P.; Demetriou, M.; Dumoulin, J.L.; Desmonts, J.M. Difficult tracheal intubation is more common in obese than in lean patients. Anesth. Analg. 2003, 97, 595-600. [CrossRef] [PubMed]

6. Lundstrom, L.H.; Moller, A.M.; Rosenstock, C.; Astrup, G.; Wetterslev, J. High body mass index is a weak predictor for difficult and failed tracheal intubation: A cohort study of 91,332 consecutive patients scheduled for direct laryngoscopy registered in the Danish Anesthesia Database. Anesthesiology 2009, 110, 266-274. [CrossRef]

7. Langeron, O.; Cuvillon, P.; Ibanez-Esteve, C.; Lenfant, F.; Riou, B.; Le Manach, Y. Prediction of difficult tracheal intubation: Time for a paradigm change. Anesthesiology 2012, 117, 1223-1233. [CrossRef] [PubMed]

8. Bilehjani, E.; Fakhari, S. Hemodynamic response to laryngoscopy in ischemic heart disease: Macintosh blade versus glidescope videolaryngoscope. Rawal Med. J. 2009, 34, 151-154.

9. Abdallah, R.; Galway, U.; You, J.; Kurz, A.; Sessler, D.I.; Doyle, D.J. A randomized comparison between the Pentax AWS video laryngoscope and the Macintosh laryngoscope in morbidly obese patients. Anesth. Analg. 2011, 113, 1082-1087. [CrossRef] [PubMed] 
10. Russell, T.; Slinger, P.; Roscoe, A.; McRae, K.; Van Rensburg, A. A randomised controlled trial comparing the GlideScope( $\left({ }^{\circledR}\right)$ and the Macintosh laryngoscope for double-lumen endobronchial intubation. Anaesthesia 2013, 68, 1253-1258. [CrossRef]

11. Arici, S.; Karaman, S.; Dogru, S.; Karaman, T.; Tapar, H.; Ozsoy, A.Z.; Kaya, Z.; Suren, M. The McGrath Series 5 video laryngoscope versus the Macintosh laryngoscope: A randomized trial in obstetric patients. Turk. J. Med. Sci. 2014, 44, 387-392. [CrossRef] [PubMed]

12. Bruck, S.; Trautner, H.; Wolff, A.; Hain, J.; Mols, G.; Pakos, P.; Roewer, N.; Lange, M. Comparison of the C-MAC() and GlideScope() videolaryngoscopes in patients with cervical spine disorders and immobilisation. Anaesthesia 2015, 70, 160-165. [CrossRef]

13. Pazur, I.; Maldini, B.; Hostic, V.; Ozegic, O.; Obraz, M. Comparison of Cormack Lehane Grading System and Intubation Difficulty Score in Patients Intubated by D-Blade Video and Direct Macintosh Laryngoscope: A Randomized Controlled Study. Acta Clin. Croat. 2016, 55, 560-564. [CrossRef]

14. Ander, F.; Magnuson, A.; Berggren, L.; Ahlstrand, R.; de Leon, A. Time-to-intubation in obese patients. A randomized study comparing direct laryngoscopy and videolaryngoscopy in experienced anesthetists. Minerva Anestesiol. 2017, 83, 906-913. [CrossRef]

15. Lu, Y.; Jiang, H.; Zhu, Y.S. Airtraq laryngoscope versus conventional Macintosh laryngoscope: A systematic review and meta-analysis. Anaesthesia 2011, 66, 1160-1167. [CrossRef] [PubMed]

16. Griesdale, D.E.; Liu, D.; McKinney, J.; Choi, P.T. Glidescope(R) video-laryngoscopy versus direct laryngoscopy for endotracheal intubation: A systematic review and meta-analysis. Can. J. Anaesth. 2012, 59, 41-52. [CrossRef] [PubMed]

17. Hoshijima, H.; Kuratani, N.; Hirabayashi, Y.; Takeuchi, R.; Shiga, T.; Masaki, E. Pentax Airway Scope(R) vs Macintosh laryngoscope for tracheal intubation in adult patients: A systematic review and meta-analysis. Anaesthesia 2014, 69, 911-918. [CrossRef] [PubMed]

18. Lewis, S.R.; Butler, A.R.; Parker, J.; Cook, T.M.; Smith, A.F. Videolaryngoscopy versus direct laryngoscopy for adult patients requiring tracheal intubation. Cochrane Database Syst. Rev. 2016, 11, CD011136. [CrossRef] [PubMed]

19. Jain, D. Scoring system for videolaryngoscopes: CL grade or POGO? Acta Anaesthesiol. Scand. 2018, 62, 1483. [CrossRef]

20. Tripathi, M.; Pandey, M. Short thyromental distance: A predictor of difficult intubation or an indicator for small blade selection? Anesthesiology 2006, 104, 1131-1136. [CrossRef]

21. Arne, J.; Descoins, P.; Fusciardi, J.; Ingrand, P.; Ferrier, B.; Boudigues, D.; Aries, J. Preoperative assessment for difficult intubation in general and ENT surgery: Predictive value of a clinical multivariate risk index. Br. J. Anaesth. 1998, 80, 140-146. [CrossRef] [PubMed]

22. Suppan, L.; Tramer, M.R.; Niquille, M.; Grosgurin, O.; Marti, C. Alternative intubation techniques vs Macintosh laryngoscopy in patients with cervical spine immobilization: Systematic review and meta-analysis of randomized controlled trials. Br. J. Anaesth. 2016, 116, 27-36. [CrossRef]

23. Higgins, J.P.; Thomas, J.; Chandler, J.; Cumpston, M.; Li, T.; Page, M.J.; Welch, V.A. Cochrane Handbook for Systematic Reviews of Interventions; John Wiley \& Sons: Hoboken, NJ, USA, 2008.

24. Brignardello-Petersen, R.; Bonner, A.; Alexander, P.E.; Siemieniuk, R.A.; Furukawa, T.A.; Rochwerg, B.; Hazlewood, G.S.; Alhazzani, W.; Mustafa, R.A.; Murad, M.H.; et al. Advances in the GRADE approach to rate the certainty in estimates from a network meta-analysis. J. Clin. Epidemiol. 2018, 93, 36-44. [CrossRef] [PubMed]

25. Higgins, J.P.; Jackson, D.; Barrett, J.K.; Lu, G.; Ades, A.E.; White, I.R. Consistency and inconsistency in network meta-analysis: Concepts and models for multi-arm studies. Res. Synth. Methods 2012, 3, 98-110. [CrossRef]

26. Chaimani, A.; Higgins, J.P.; Mavridis, D.; Spyridonos, P.; Salanti, G. Graphical tools for network meta-analysis in STATA. PLoS ONE 2013, 8, e76654. [CrossRef]

27. Ahmed, S.M.; Doley, K.; Athar, M.; Raza, N.; Siddiqi, O.A.; Ali, S. Comparison of endotracheal intubation time in neutral position between C-Mac and Airtraq laryngoscopes: A prospective randomised study. Indian J. Anaesth. 2017, 61, 338-343. [CrossRef] [PubMed]

28. Akbar, S.H.M.; Ooi, J.S.M. Comparison between C-MAC video-laryngoscope and macintosh direct laryngoscope during cervical spine immobilization. Middle East J. Anaesthesiol. 2015, 23, 43-50. [PubMed]

29. Akbas, S.; Ozkan, A.S.; Karaaslan, E. A Comparison of McGrath MAC Versus C-MAC Videolaryngoscopes in Morbidly Obese Patients Undergoing Bariatric Surgery: A Randomized, Controlled Clinical Trial. Bariatr. Surg. Pract. Patient Care 2019, 14, 25-33. [CrossRef]

30. Al-Ghamdi, A.A.; El Tahan, M.R.; Khidr, A.M. Comparison of the Macintosh, GlideScope, Airtraq, and King VisionTM laryngoscopes in routine airway management. Minerva Anestesiol. 2016, 82, 1278-1287. [PubMed]

31. Ali, Q.E.; Amir, S.H.; Ahmad, S. A comparative evaluation of King Vision video laryngoscope (Channelled blade), McCoy, and Macintosh laryngoscopes for tracheal intubation in patients with immobilized cervical spine. Sri Lankan J. Anaesthesiol. 2017, 25, 70-75. [CrossRef]

32. Ali, Q.E.; Amir, S.H.; Jamil, S.; Ahmad, S. A comparative evaluation of the Airtraq and King Vision video laryngoscope as an intubating aid in adult patients. Acta Anaesthesiol. Belg. 2015, 66, 81-85. [PubMed]

33. Ali, Q.E.; Amir, S.H.; Siddiqui, O.A.; Mahopatra, P.S. A comparative evaluation of conventional Macintosh laryngoscope and the Airtraq in different intubation scenarios. Sri Lankan J. Anaesthesiol. 2012, 20, 3-6. [CrossRef] 
34. Amini, S.; Shakib, M. Hemodynamic changes following endotracheal intubation in patients undergoing cesarean section with general anesthesia: Application of glidescope videolaryngoscope versus direct laryngoscope. Anesthesiol. Pain Med. 2015, 5, e21836. [CrossRef] [PubMed]

35. Aoi, Y.; Inagawa, G.; Nakamura, K.; Sato, H.; Kariya, T.; Goto, T. Airway scope versus macintosh laryngoscope in patients with simulated limitation of neck movements. J. Trauma 2010, 69, 838-842. [CrossRef] [PubMed]

36. Aqil, M.; Khan, M.U.; Hussain, A.; Khokhar, R.S.; Mansoor, S.; Alzahrani, T. Routine Use of Glidescope and Macintosh Laryngoscope by Trainee Anesthetists. J. Coll. Physicians Surg. Pak. JCPSP 2016, 26, 245-249. [PubMed]

37. Aqil, M.; Khan, M.U.; Mansoor, S.; Mansoor, S.; Khokhar, R.S.; Narejo, A.S. Incidence and severity of postoperative sore throat: A randomized comparison of Glidescope with Macintosh laryngoscope. BMC Anesthesiol. 2017, 17, 127. [CrossRef] [PubMed]

38. Bakshi, S.G.; Gawri, A.; Divatia, J.V. McGrath MAC video laryngoscope versus direct laryngoscopy for the placement of double-lumen tubes: A randomised control trial. Indian J. Anaesth. 2019, 63, 456-461. [CrossRef] [PubMed]

39. Belze, O.; Lepage, E.; Bazin, Y.; Kerourin, P.; Fusciardi, J.; Remerand, F.; Espitalier, F. Glidescope versus Airtraq DL for doublelumen tracheal tube insertion in patients with a predicted or known difficult airway: A randomised study. Eur. J. Anaesthesiol. 2017, 34, 456-463. [CrossRef] [PubMed]

40. Bhandari, G.; Shahi, K.S.; Asad, M.; Bhakuni, R. Airtraq() versus Macintosh laryngoscope: A comparative study in tracheal intubation. Anesth. Essays Res. 2013, 7, 232-236. [CrossRef]

41. Blajic, I.; Hodzovic, I.; Lucovnik, M.; Mekis, D.; Novak-Jankovic, V.; Stopar Pintaric, T. A randomised comparison of C-MAC and King Vision(R) videolaryngoscopes with direct laryngoscopy in 180 obstetric patients. Int. J. Obs. Anesth. 2019, $39,35-41$. [CrossRef] [PubMed]

42. Çaparlar, C.Ö.; Aydın, G.B.; Sezer, E.; Ergil, J.; Doğan, A.Ş. A comparison of C-MAC videolaryngoscope and Macintosh laryngoscope in intraocular pressure changes, throat pain, intubation time and hemodynamic variables. Eur. Res. J. 2019, 5, 745-750. [CrossRef]

43. Cavus, E.; Thee, C.; Moeller, T.; Kieckhaefer, J.; Doerges, V.; Wagner, K. A randomised, controlled crossover comparison of the C-MAC videolaryngoscope with direct laryngoscopy in 150 patients during routine induction of anaesthesia. BMC Anesthesiol. 2011, 11, 6. [CrossRef]

44. Chalkeidis, O.; Kotsovolis, G.; Kalakonas, A.; Filippidou, M.; Triantafyllou, C.; Vaikos, D.; Koutsioumpas, E. A comparison between the Airtraq and Macintosh laryngoscopes for routine airway management by experienced anesthesiologists: A randomized clinical trial. Acta Anaesthesiol. Taiwanica Off. J. Taiwan Soc. Anesthesiol. 2010, 48, 15-20. [CrossRef]

45. Chandrashekaraiah, M.M.; Shah, V.H.; Pandey, V.C.; Adeel, S. Evaluation of ease of intubation using C-MAC vs Macintosh laryngoscope in patients with the application of manual inline axial stabilization-A randomized comparative study. Sri Lankan J. Anaesthesiol. 2017, 25, 8-12. [CrossRef]

46. Dhonneur, G.; Abdi, W.; Ndoko, S.K.; Amathieu, R.; Risk, N.; El Housseini, L.; Polliand, C.; Champault, G.; Combes, X.; Tual, L. Video-assisted versus conventional tracheal intubation in morbidly obese patients. Obes. Surg. 2009, 19, 1096-1101. [CrossRef]

47. El-Tahan, M.R.; El Kenany, S.; Khidr, A.M.; Al Ghamdi, A.A.; Tawfik, A.M.; Al Mulhim, A.S. Cervical spine motion during tracheal intubation with King VisionTM video laryngoscopy and conventional laryngoscopy: A crossover randomized study. Minerva Anestesiol. 2017, 83, 1152-1160. [CrossRef]

48. El-Tahan, M.R.; Khidr, A.M.; Gaarour, I.S.; Alshadwi, S.A.; Alghamdi, T.M.; Al'ghamdi, A. A Comparison of 3 Videolaryngoscopes for Double-Lumen Tube Intubation in Humans by Users With Mixed Experience: A Randomized Controlled Study. J. Cardiothorac. Vasc. Anesth. 2018, 32, 277-286. [CrossRef]

49. Enomoto, Y.; Asai, T.; Arai, T.; Kamishima, K.; Okuda, Y. Pentax-AWS, a new videolaryngoscope, is more effective than the Macintosh laryngoscope for tracheal intubation in patients with restricted neck movements: A randomized comparative study. Br. J. Anaesth. 2008, 100, 544-548. [CrossRef]

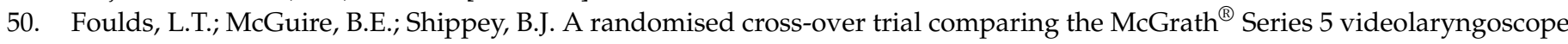
with the Macintosh laryngoscope in patients with cervical spine immobilisation. Anaesthesia 2016, 71, 437-442. [CrossRef]

51. Gupta, N.; Rath, G.P.; Prabhakar, H. Clinical evaluation of C-MAC videolaryngoscope with or without use of stylet for endotracheal intubation in patients with cervical spine immobilization. J. Anesth. 2013, 27, 663-670. [CrossRef] [PubMed]

52. Hosalli, V.; Arjun, B.K.; Ambi, U.; Hulakund, S. Comparison of AirtraqTM, McCoyTM and Macintosh laryngoscopes for endotracheal intubation in patients with cervical spine immobilisation: A randomised clinical trial. Indian J. Anaesth. 2017, 61, 332-337. [CrossRef] [PubMed]

53. Hsu, H.T.; Chou, S.H.; Wu, P.J.; Tseng, K.Y.; Kuo, Y.W.; Chou, C.Y.; Cheng, K.I. Comparison of the GlideScope ${ }^{\circledR v i d e o l a r y n g o s c o p e ~}$ and the Macintosh laryngoscope for double-lumen tube intubation. Anaesthesia 2012, 67, 411-415. [CrossRef] [PubMed]

54. Hu, B.; Zhou, H.; Wang, J.; Li, Y.; Luo, J. Glidescope video laryngoscope vs. Macintosh direct laryngoscope for the intubation of laryngeal neoplasm patients: A randomized controlled study. Int. J. Clin. Exp. Med. 2017, 10, 13639-13645.

55. Ilyas, S.; Symons, J.; Bradley, W.P.L.; Segal, R.; Taylor, H.; Lee, K.; Balkin, M.; Bain, C.; Ng, I. A prospective randomised controlled trial comparing tracheal intubation plus manual in-line stabilisation of the cervical spine using the Macintosh laryngoscope vs the McGrath() Series 5 videolaryngoscope. Anaesthesia 2014, 69, 1345-1350. [CrossRef]

56. Jafra, A.; Gombar, S.; Kapoor, D.; Sandhu, H.S.; Kumari, K. A prospective randomized controlled study to evaluate and compare GlideScope with Macintosh laryngoscope for ease of endotracheal intubation in adult patients undergoing elective surgery under general anesthesia. Saudi J. Anaesth. 2018, 12, 272-278. [CrossRef] [PubMed] 
57. Jeon, W.J.; Kim, K.H.; Yeom, J.H.; Bang, M.R.; Hong, J.B.; Cho, S.Y. A comparison of the glidescopespi to the mcgrath videolaryngoscope in patients. Korean J. Anesthesiol. 2011, 61, 19-23. [CrossRef] [PubMed]

58. Kido, H.; Komasawa, N.; Matsunami, S.; Kusaka, Y.; Minami, T. Comparison of McGRATH MAC and Macintosh laryngoscopes for double-lumen endotracheal tube intubation by anesthesia residents: A prospective randomized clinical trial. J. Clin. Anesth. 2015, 27, 476-480. [CrossRef] [PubMed]

59. Kim, M.K.; Park, S.W.; Lee, J.W. Randomized comparison of the Pentax AirWay Scope and Macintosh laryngoscope for tracheal intubation in patients with obstructive sleep apnoea. Br. J. Anaesth. 2013, 111, 662-666. [CrossRef] [PubMed]

60. Kleine-Brueggeney, M.; Buttenberg, M.; Greif, R.; Nabecker, S.; Theiler, L. Evaluation of three unchannelled videolaryngoscopes and the Macintosh laryngoscope in patients with a simulated difficult airway: A randomised, controlled trial. Anaesthesia 2017, 72, 370-378. [CrossRef]

61. Kleine-Brueggeney, M.; Greif, R.; Schoettker, P.; Savoldelli, G.L.; Nabecker, S.; Theiler, L.G. Evaluation of six videolaryngoscopes in 720 patients with a simulated difficult airway: A multicentre randomized controlled trial. Br. J. Anaesth. 2016, 116, 670-679. [CrossRef] [PubMed]

62. Lange, M.; Frommer, M.; Redel, A.; Trautner, H.; Hampel, J.; Kranke, P.; Kehl, F.; Scholtz, L.U.; Roewer, N. Comparison of the Glidescope and Airtraq optical laryngoscopes in patients undergoing direct microlaryngoscopy. Anaesthesia 2009, 64, 323-328. [CrossRef] [PubMed]

63. Lee, H. The Pentax airway scope versus the Macintosh laryngoscope: Comparison of hemodynamic responses and concentrations of plasma norepinephrine to tracheal intubation. Korean J. Anesthesiol. 2013, 64, 315-320. [CrossRef] [PubMed]

64. Lee, J.; Kwak, H.J.; Lee, J.Y.; Chang, M.Y.; Lee, S.Y.; Kim, J.Y. Comparison of the Pentax AirwayScope and McGrath MAC videolaryngoscope for endotracheal intubation in patients with a normal airway. Medicine 2017, 96, e8713. [CrossRef] [PubMed]

65. Lee, R.A.; van Zundert, A.A.J.; Maassen, R.L.J.G.; Wieringa, P.A. Forces applied to the maxillary incisors by video laryngoscopes and the Macintosh laryngoscope. Acta Anaesthesiol. Scand. 2012, 56, 224-229. [CrossRef]

66. Lim, Y.; Yeo, S.W. A comparison of the GlideScope with the Macintosh laryngoscope for tracheal intubation in patients with simulated difficult airway. Anaesth. Intensive Care 2005, 33, 243-247. [CrossRef] [PubMed]

67. Liu, E.H.C.; Goy, R.W.L.; Tan, B.H.; Asai, T. Tracheal intubation with videolaryngoscopes in patients with cervical spine immobilization: A randomized trial of the Airway Scope and the GlideScope. Br. J. Anaesth. 2009, 103, 446-451. [CrossRef] [PubMed]

68. Maharaj, C.H.; Buckley, E.; Harte, B.H.; Laffey, J.G. Endotracheal intubation in patients with cervical spine immobilization: A comparison of macintosh and airtraq laryngoscopes. Anesthesiology 2007, 107, 53-59. [CrossRef]

69. Maharaj, C.H.; Costello, J.F.; Harte, B.H.; Laffey, J.G. Evaluation of the Airtraq and Macintosh laryngoscopes in patients at increased risk for difficult tracheal intubation. Anaesthesia 2008, 63, 182-188. [CrossRef]

70. Maharaj, C.H.; O'Croinin, D.; Curley, G.; Harte, B.H.; Laffey, J.G. A comparison of tracheal intubation using the Airtraq or the Macintosh laryngoscope in routine airway management: A randomised, controlled clinical trial. Anaesthesia 2006, 61, 1093-1099. [CrossRef] [PubMed]

71. Malik, M.A.; Maharaj, C.H.; Harte, B.H.; Laffey, J.G. Comparison of Macintosh, Truview EVO2, Glidescope, and Airwayscope laryngoscope use in patients with cervical spine immobilization. Br. J. Anaesth. 2008, 101, 723-730. [CrossRef]

72. Malik, M.A.; Subramaniam, R.; Churasia, S.; Maharaj, C.H.; Harte, B.H.; Laffey, J.G. Tracheal intubation in patients with cervical spine immobilization: A comparison of the Airwayscope ${ }^{\circledR}$, LMA CTrach ${ }^{\circledR}$, and the Macintosh laryngoscopes. Br. J. Anaesth. 2009, 102, 654-661. [CrossRef]

73. Malik, M.A.; Subramaniam, R.; Maharaj, C.H.; Harte, B.H.; Laffey, J.G. Randomized controlled trial of the Pentax AWS, Glidescope, and Macintosh laryngoscopes in predicted difficult intubation. Br. J. Anaesth. 2009, 103, 761-768. [CrossRef]

74. Maruyama, K.; Nakagawa, H.; Imanishi, H.; Kitamura, A.; Hayashida, M. Comparison of postoperative pharyngeal morbidity using the Macintosh laryngoscope or AirWay Scope after mastectomy. J. Anesth. 2011, 25, 773-776. [CrossRef]

75. Maruyama, K.; Yamada, T.; Kawakami, R.; Hara, K. Randomized cross-over comparison of cervical-spine motion with the AirWay Scope or Macintosh laryngoscope with in-line stabilization: A video-fluoroscopic study. Br. J. Anaesth. 2008, 101, 563-567. [CrossRef]

76. Mathew, N.; Gaude, Y.K.; Joseph, T.T.; Kini, K.G. Comparison of haemodynamic responses to tracheal intubation using macintosh and airtraq laryngoscope in patients with simulated cervical spine injury. Sri Lankan J. Anaesthesiol. 2018, 26, 124-130. [CrossRef]

77. McElwain, J.; Laffey, J.G. Comparison of the C-MAC, Airtraq, and Macintosh laryngoscopes in patients undergoing tracheal intubation with cervical spine immobilization. Br. J. Anaesth. 2011, 107, 258-264. [CrossRef]

78. Mendonca, C.; Ungureanu, N.; Nowicka, A.; Kumar, P. A randomised clinical trial comparing the 'sniffing' and neutral position using channelled (KingVision) and non-channelled (C-MAC) videolaryngoscopes. Anaesthesia 2018, 73, 847-855. [CrossRef]

79. Najafi, A.; Imani, F.; Makarem, J.; Khajavi, M.R.; Etezadi, F.; Habibi, S.; Shariat Moharari, R. Postoperative sore throat after laryngoscopy with macintosh or glide scope video laryngoscope blade in normal airway patients. Anesthesiol. Pain Med. 2014, 4, e15136. [CrossRef]

80. Nandakumar, K.P.; Bhalla, A.P.; Pandey, R.K.; Baidya, D.K.; Subramaniam, R.; Kashyap, L. Comparison of Macintosh, McCoy, and Glidescope video laryngoscope for intubation in morbidly obese patients: Randomized controlled trial. Saudi J. Anaesth. 2018, 12, 433-439. [CrossRef] 
81. Ndoko, S.K.; Amathieu, R.; Tual, L.; Polliand, C.; Kamoun, W.; El Housseini, L.; Champault, G.; Dhonneur, G. Tracheal intubation of morbidly obese patients: A randomized trial comparing performance of Macintosh and Airtraq laryngoscopes. Br. J. Anaesth. 2008, 100, 263-268. [CrossRef]

82. Ng, I.; Hill, A.L.; Williams, D.L.; Lee, K.; Segal, R. Randomized controlled trial comparing the McGrath videolaryngoscope with the C-MAC videolaryngoscope in intubating adult patients with potential difficult airways. Br. J. Anaesth. 2012, 109, 439-443. [CrossRef] [PubMed]

83. Ninan, J.E.; Ranjan, R.V.; Ramachandran, T.R.; George, S.K. C-MAC videolaryngoscope improves the laryngoscopy view in Mallampati class 2 and 3 patients. Anaesth. Pain Intensive Care 2016, 20, 261-265.

84. Nishikawa, K.; Matsuoka, H.; Saito, S. Tracheal intubation with the PENTAX-AWS (airway scope) reduces changes of hemodynamic responses and bispectral index scores compared with the Macintosh laryngoscope. J. Neurosurg. Anesthesiol. 2009, 21, 292-296. [CrossRef]

85. Parasa, M.; Yallapragada, S.V.; Vemuri, N.N.; Shaik, M.S. Comparison of GlideScope video laryngoscope with Macintosh laryngoscope in adult patients undergoing elective surgical procedures. Anesth. Essays Res. 2016, 10, 245-249. [CrossRef]

86. Ranieri, D.; Filho, S.M.; Batista, S.; do Nascimento, P. Comparison of Macintosh and Airtraq ${ }^{\mathrm{TM}}$ laryngoscopes in obese patients placed in the ramped position. Anaesthesia 2012, 67, 980-985. [CrossRef]

87. Raza, N.; Hasan, M.; Ahmed, S.M.; Bano, S.; Athar, M. A comparative study of McGrath and Airtraq videolaryngoscopes for tracheal intubation. J. Anaesthesiol. Clin. Pharmacol. 2017, 33, 221-225. [CrossRef]

88. Reena. Comparison of King Vision video laryngoscope (channeled blade) with Macintosh laryngoscope for tracheal intubation using armored endotracheal tubes. J. Anaesthesiol. Clin. Pharm. 2019, 35, 359-362. [CrossRef]

89. Sahajanandan, R.; Dhanyee, A.S.; Gautam, A.K. A comparison of King vision video laryngoscope with CMAC D-blade in obese patients with anticipated difficult airway in tertiary hospital in India-Randomized control study. J. Anaesthesiol. Clin. Pharm. 2019, 35, 363-367. [CrossRef]

90. Sargin, M.; Uluer, M.S. Comparison of McGrath() Series 5 video laryngoscope with Macintosh laryngoscope: A prospective, randomised trial in patients with normal airways. Pak. J. Med. Sci. 2016, 32, 869-874. [CrossRef] [PubMed]

91. Sarkilar, G.; Sargin, M.; Saritas, T.B.; Borazan, H.; Gok, F.; Kilicaslan, A.; Otelcioglu, S. Hemodynamic responses to endotracheal intubation performed with video and direct laryngoscopy in patients scheduled for major cardiac surgery. Int. J. Clin. Exp. Med. 2015, 8, 11477-11483. [PubMed]

92. Serocki, G.; Neumann, T.; Scharf, E.; Dorges, V.; Cavus, E. Indirect videolaryngoscopy with C-MAC D-Blade and GlideScope: A randomized, controlled comparison in patients with suspected difficult airways. Minerva Anestesiol. 2013, 79, 121-129. [PubMed]

93. Shah, S.B.; Bhargava, A.K.; Hariharan, U.; Mittal, A.K.; Goel, N.; Choudhary, M. A Randomized Clinical Trial Comparing the Standard Mcintosh Laryngoscope and the C-Mac D blade Video laryngoscopeTM for Double Lumen Tube Insertion for One Lung Ventilation in Onco surgical Patients. Indian J. Anaesth. 2016, 60, 312-318. [CrossRef] [PubMed]

94. Shravanalakshmi, D.; Bidkar, P.U.; Narmadalakshmi, K.; Lata, S.; Mishra, S.K.; Adinarayanan, S. Comparison of intubation success and glottic visualization using King Vision and C-MAC videolaryngoscopes in patients with cervical spine injuries with cervical immobilization: A randomized clinical trial. Surg. Neurol. Int. 2017, 8, 19. [CrossRef] [PubMed]

95. Siddiqui, N.; Katznelson, R.; Friedman, Z. Heart rate/blood pressure response and airway morbidity following tracheal intubation with direct laryngoscopy, GlideScope and Trachlight: A randomized control trial. Eur. J. Anaesthesiol. 2009, 26, 740-745. [CrossRef] [PubMed]

96. Sun, D.A.; Warriner, C.B.; Parsons, D.G.; Klein, R.; Umedaly, H.S.; Moult, M. The GlideScope Video Laryngoscope: Randomized clinical trial in 200 patients. Br. J. Anaesth. 2005, 94, 381-384. [CrossRef]

97. Taylor, A.M.; Peck, M.; Launcelott, S.; Hung, O.R.; Law, J.A.; MacQuarrie, K.; McKeen, D.; George, R.B.; Ngan, J. The McGrath ${ }^{\circledR}$ Series 5 videolaryngoscope vs the Macintosh laryngoscope: A randomised, controlled trial in patients with a simulated difficult airway. Anaesthesia 2013, 68, 142-147. [CrossRef]

98. Tempe, D.K.; Chaudhary, K.; Diwakar, A.; Datt, V.; Virmani, S.; Tomar, A.S.; Mohandas, A.; Mohire, V.B. Comparison of hemodynamic responses to laryngoscopy and intubation with Truview PCD ${ }^{\mathrm{TM}}$, McGrath®and Macintosh laryngoscope in patients undergoing coronary artery bypass grafting: A randomized prospective study. Ann. Card. Anaesth. 2016, 19, 68-75. [CrossRef]

99. Teoh, W.H.L.; Saxena, S.; Shah, M.K.; Sia, A.T.H. Comparison of three videolaryngoscopes: Pentax Airway Scope, C-MAC, Glidescope vs the Macintosh laryngoscope for tracheal intubation. Anaesthesia 2010, 65, 1126-1132. [CrossRef]

100. Teoh, W.H.L.; Shah, M.K.; Sia, A.T.H. Randomised comparison of Pentax AirwayScope and Glidescope for tracheal intubation in patients with normal airway anatomy. Anaesthesia 2009, 64, 1125-1129. [CrossRef]

101. Toker, M.K.; Altiparmak, B.; Karabay, A.G. Comparison of the McGrath video laryngoscope and macintosh direct laryngoscope in obstetric patients: A randomized controlled trial. Pak. J. Med. Sci 2019, 35, 342-347. [CrossRef]

102. Tolon, M.A.; Zanaty, O.M.; Shafshak, W.; Arida, E.E. Comparative study between the use of Macintosh Laryngoscope and Airtraq in patients with cervical spine immobilization. Alex. J. Med. 2012, 48, 179-185. [CrossRef]

103. Tosh, P.; Kadapamannil, D.; Rajan, S.; Narayani, N.; Kumar, L. Effect of C-MAC Video Laryngoscope-aided intubations Using D-Blade on Incidence and Severity of Postoperative Sore Throat. Anesth. Essays Res. 2018, 12, 140-144. [CrossRef] [PubMed]

104. Turkstra, T.P.; Cusano, F.; Fridfinnson, J.A.; Batohi, P.; Rachinsky, M. Early Endotracheal Tube Insertion with the GlideScope: A Randomized Controlled Trial. Anesth. Analg. 2016, 122, 753-757. [CrossRef] [PubMed] 
105. Varsha, A.V.; George, G.; Pillai, R.; Sahajanandan, R. Comparative evaluation of hemodynamic responses and ease of intubation with airtraq video laryngoscope versus macintosh laryngoscope in patients with ischemic heart disease. Ann. Card Anaesth. 2019, 22, 365-371. [CrossRef]

106. Vijayakumar, V.; Rao, S.; Shetty, N. A Comparison of Macintosh and Airtraq Laryngoscopes for Endotracheal Intubation in Adult Patients With Cervical Spine Immobilization Using Manual In Line Axial Stabilization: A Prospective Randomized Study. J. Neurosurg. Anesthesiol. 2016, 28, 296-302. [CrossRef] [PubMed]

107. Wan, L.; Liao, M.; Li, L.; Qian, W.; Hu, R.; Chen, K.; Zhang, C.; Yao, W. McGrath Series 5 videolaryngoscope vs Airtraq DL videolaryngoscope for double-lumen tube intubation: A randomized trial. Medicine 2016, 95, e5739. [CrossRef] [PubMed]

108. Wasem, S.; Lazarus, M.; Hain, J.; Festl, J.; Kranke, P.; Roewer, N.; Lange, M.; Smul, T.M. Comparison of the Airtraq and the Macintosh laryngoscope for double-lumen tube intubation: A randomised clinical trial. Eur. J. Anaesthesiol. 2013, 30, 180-186. [CrossRef] [PubMed]

109. Wasinwong, W.; Pukdeetanakul, V.; Kanchanawanitkul, O.; Sriyannaluk, B. Comparison of Intubation Time with GlideScope and McIntosh Laryngoscope in Obese Patients. J. Med. Assoc. Thail. Chotmaihet Thangphaet 2017, 100, 306-312.

110. Woo, C.-H.; Kim, S.H.; Park, J.-Y.; Bae, J.Y.; Kwak, I.-S.; Mun, S.H.; Kim, K.-M. Macintosh laryngoscope vs. Pentax-AWS video laryngoscope: Comparison of efficacy and cardiovascular responses to tracheal intubation in major burn patients. Korean J. Anesthesiol. 2012, 62, 119-124. [CrossRef] [PubMed]

111. Xue, F.S.; Zhang, G.H.; Li, X.Y.; Sun, H.T.; Li, P.; Li, C.W.; Liu, K.P. Comparison of hemodynamic responses to orotracheal intubation with the GlideScope videolaryngoscope and the Macintosh direct laryngoscope. J. Clin. Anesth. 2007, 19, 245-250. [CrossRef]

112. Yao, W.L.; Wan, L.; Xu, H.; Qian, W.; Wang, X.R.; Tian, Y.K.; Zhang, C.H. A comparison of the McGrath Series 5 videolaryngoscope and Macintosh laryngoscope for double-lumen tracheal tube placement in patients with a good glottic view at direct laryngoscopy. Anaesthesia 2015, 70, 810-817. [CrossRef] [PubMed]

113. Yi, J.; Gong, Y.; Quan, X.; Huang, Y. Comparison of the Airtraq laryngoscope and the GlideScope for double-lumen tube intubation in patients with predicted normal airways: A prospective randomized trial. BMC Anesthesiol. 2015, 15, 58. [CrossRef] [PubMed]

114. Yoo, J.Y.; Park, S.Y.; Kim, J.Y.; Kim, M.; Haam, S.J.; Kim, D.H. Comparison of the McGrath videolaryngoscope and the Macintosh laryngoscope for double lumen endobronchial tube intubation in patients with manual in-line stabilization: A randomized controlled trial. Medicine 2018, 97, e0081. [CrossRef] [PubMed]

115. Yumul, R.; Elvir-Lazo, O.L.; White, P.F.; Sloninsky, A.; Kaplan, M.; Kariger, R.; Naruse, R.; Parker, N.; Pham, C.; Zhang, X.; et al. Comparison of three video laryngoscopy devices to direct laryngoscopy for intubating obese patients: A randomized controlled trial. J. Clin. Anesth. 2016, 31, 71-77. [CrossRef]

116. Maruyama, K.; Yamada, T.; Kawakami, R.; Kamata, T.; Yokochi, M.; Hara, K. Upper cervical spine movement during intubation: Fluoroscopic comparison of the AirWay Scope, McCoy laryngoscope, and Macintosh laryngoscope. Br. J. Anaesth. 2008, 100, 120-124. [CrossRef] [PubMed]

117. De Jong, A.; Molinari, N.; Conseil, M.; Coisel, Y.; Pouzeratte, Y.; Belafia, F.; Jung, B.; Chanques, G.; Jaber, S. Video laryngoscopy versus direct laryngoscopy for orotracheal intubation in the intensive care unit: A systematic review and meta-analysis. Intensive Care Med. 2014, 40, 629-639. [CrossRef] [PubMed]

118. Rombey, T.; Schieren, M.; Pieper, D. Video Versus Direct Laryngoscopy for Inpatient Emergency Intubation in Adults. Dtsch. Arztebl. Int. 2018, 115, 437-444. [CrossRef]

119. Seo, K.H.; Kim, K.M.; John, H.; Jun, J.H.; Han, M.; Kim, S. Comparison of C-MAC D-blade videolaryngoscope and McCoy laryngoscope efficacy for nasotracheal intubation in simulated cervical spinal injury: A prospective randomized comparative study. BMC Anesth. 2020, 20, 114. [CrossRef]

120. Kim, Y.S.; Song, J.; Lim, B.G.; Lee, I.O.; Won, Y.J. Different classes of videoscopes and direct laryngoscopes for double-lumen tube intubation in thoracic surgery: A systematic review and network meta-analysis. PLoS ONE 2020, 15, e0238060. [CrossRef]

121. Kim, W.; Choi, H.J.; Lim, T.; Kang, B.S. Can the new McGrath laryngoscope rival the GlideScope Ranger portable video laryngoscope? A randomized manikin study. Am. J. Emerg. Med. 2014, 32, 1225-1229. [CrossRef] [PubMed] 